\title{
The effects of Brexit on credit spreads: Evidence from UK and Eurozone corporate bond markets
}

\author{
Samir Kadiric ${ }^{1} \cdot$ Arthur Korus $^{1}$
}

Published online: 19 January 2019

(C) The Author(s) 2019

\begin{abstract}
Using event-study techniques, we investigate the impact of Brexit-related events on the corporate bond yield spreads in the United Kingdom and Eurozone, respectively. We want to find out whether Brexit-related news, including the Brexit referendum itself, had an impact on the risk conditions in those two corporate bond markets. Our estimation results indicate that the announcement of the referendum result is associated with increasing credit spreads in the UK and EA. However, only the actual announcement of the UK referendum result itself had an influence on the credit spreads. Furthermore, we distinguish between the financial and the non-financial economic sectors in order to analyze more specific sector-related effects of the referendum event. Our estimation results suggest that UK credit spreads were more strongly influenced by the announcement of the results of the Brexit referendum than credit bond spreads in the Eurozone were. Finally, we split our sample into pre-referendum and postreferendum periods to consider the potential changing evaluation of the determinants of corporate bond spreads due to altering risk pricing triggered by the Brexit referendum result. We find that the effect of credit default risk is far stronger and plays a significant role in the post-referendum period in UK and EA, respectively.
\end{abstract}

Keywords Corporate bond yield spreads · Credit risk · Brexit · Event-study

JEL classification $\mathrm{C} 32 \cdot \mathrm{G} 12 \cdot \mathrm{G} 14 \cdot \mathrm{G} 32$

Samir Kadiric

kadiric@eiiw.uni-wuppertal.de

Arthur Korus

korus@eiiw.uni-wuppertal.de

1 European Institute for International Economic Relations (EIIW), University of Wuppertal, Rainer-Gruenter-Str. 21, 42119 Wuppertal, Germany 


\section{Introduction}

Brexit represents a major institutional and political change for the United Kingdom and the EU27/Eurozone and thus could change the perception of risk with regard to both UK and Eurozone bonds. With the EU aiming to complete the banking union and the capital market union, respectively - with effectively a strong focus on the Eurozone the role of corporate bonds markets in the Eurozone has increased, while in the UK corporate bonds have traditionally played a large role. From this perspective, the issue as to what extent Brexit will affect the corporate bond markets in the EU28 is all the more important. In our analysis we try to capture and measure the effect of the UK's decision to leave EU28 (Brexit) on the risk conditions in the United Kingdom (UK) and euro area (EA), i.e. Eurozone, corporate bond markets.

As yields are intensely disposed to variations in the overall bond market, they do not represent an appropriate way to capture and analyze risk conditions in the corporate bond market. On account of this, in our study we use the yield spread (sometimes just called the credit spread), i.e. that part of corporate bond yield that is above the yield of risk-free bonds - most prevalently government bonds with an equivalent maturity. The resulting corporate bond yield spreads as an indicator of a risk premium are expected to express the risk conditions exposure of firms in the UK and Eurozone. This issue is of key importance from a corporate finance but also from a policymaker's perspective because the UK's leaving of the EU (most probably on March 29th, 2019) will directly affect capital market structure as well as the timing of debt and fund-rising decisions.

Hence, our paper is related to the literature which focuses on the short-term effects of Brexit on financial markets. These studies elaborate on the impact of Brexit on stock markets, exchange rates, and interest rates. Davies and Studnicka (2017) analyze the effects of Brexit-related events on stock movements in the UK by using event study methods. They find that the announcement of the referendum's result led to a sharp decline of the FTSE 350. Also by conducting an event study, Ramiahet al. (2017) find that stock prices of financials were particularly affected by the Brexit referendum. Belke et al. (2016) study the impact of Brexit on policy uncertainty and international financial markets. They find that international stock markets were affected by an increase in the probability of Brexit. Moreover, Belke et al. (2016) find that European stock market indices were affected by an increase in the likelihood of Brexit and that the effects between European countries were similar.

By applying long-memory techniques, Caporale, Gil-Alana, and Trani (Caporale et al. 2018) find that the Brexit referendum led to significant changes in the degree of persistence of the FTSE 100 Implied Volatility Index and on the British pound's implied volatility vis-à-vis the euro and the US dollar, respectively. Many studies also elaborate on the impact of Brexit on exchange rates. For instance, Korus and Celebi (2018) examine the impact of Brexit-related news on the spot exchange rate of the British pound against the euro. By splitting Brexit-related events into 'good' Brexit news and 'bad' Brexit news, they find that, bad Brexit news is associated with a depreciation of the British pound against the euro whereas good Brexit news appreciates the Pound sterling against the euro. The Bank of England (2016) examines the impact of the Brexit referendum on interest rates in the United Kingdom. It finds no clear impact of referendum-related news on short-term interest rates. Belke et al. (2016) also elaborate on the impact of Brexit on long-term interest rates. Their empirical 
results suggest that an increase in the Brexit probability decreased 10-year government bond yields in the UK and in risk-free countries, respectively. However, they do find that sovereign CDS for 10-year government bonds increased in the UK due to Brexit. This could suggest that there are no broadly convergent expectations amongst financial market actors which would not be surprising given the fact that Brexit is a historical and unprecedented change in EU integration.

A key aspect of our research in this paper is to determine and quantify the impact of Brexit-related events on risk conditions in the UK and EA corporate bond markets, respectively. We focus on the yield spread of corporate bonds, defined as the yield differential of a corporate bond relative to that of a benchmark government bond yield with a similar maturity. We use daily data for the period from January 2013 to March 2018. We consider major determinants of corporate bond yield spreads, which are largely based and affirmed by previous studies in this field.

Several findings are of a particular interest. First, we investigate whether the announcement of the Brexit referendum result had an impact on UK and EA credit spreads for bonds with a remaining maturity of $1-3$ years, 3-5 years, 5-7 years, 7-10 years and $10+$ years, including all rating groups, respectively. We find that the effect of the referendum outcome on corporate bond markets is stronger in the UK market than in the EA market. Second, differentiating between the financial and the non-financial economic sectors allows us to analyze more specific sector-related effects of the referendum result. Our results indicate that the impact of Brexit on credit spreads for a given maturity is higher for financials than for non-financials, especially in the EA where corporate bond spreads in the non-financial sector were hardly or not at all affected by the referendum result. Third, we split our sample into pre-referendum and post-referendum periods, to consider the potential changing evaluation of the determinants of corporate bond spreads due to altering risk pricing triggered by the Brexit referendum result. We find that the impact of determining variables on corporate bond yield spreads in the UK and EA is not constant over time and that particularly the effect of credit default risk is far stronger and plays a significant role in the post-referendum period in UK and EA, respectively.

This paper differs from others in that, to the best of our knowledge, we are the first to analyze the impact of Brexit on corporate bond yield spreads in the UK and EA. Further contributions of this study are as follows: (I) It extends the existing literature on corporate bond yield spreads in the UK and EA, which to date is rather scarce, while (II) analyzing the UK and EA corporate bond markets simultaneously allows for a direct comparison of the two markets and (III) it is the first to use the forward swap market as an explanatory variable for credit spread.

The reminder of this paper is organized as follows. Section 2 presents the theoretical background and gives a review of related empirical literature. Section 3 presents the data used in this study. In section 4, we examine the theoretical determinants of credit spreads and discuss our empirical results. Section 5 delivers time-varying estimation results before, section 6 finally concludes.

\section{Theoretical background and related literature}

The leading theoretical framework for studying the pricing of corporate debt was developed by Black and Scholes (1973) and Merton (1974). Black and Scholes 
(1973) presented a complete general equilibrium theory of the pricing of options and corporate liabilities, though the focus of their analysis lay on valuing options. Both Merton (1974) and Black and Scholes (1973) presciently recognized that a similar analysis could be applied to all corporate securities and became leading contributions in the development of pricing theory for corporate liabilities in general. According to Merton (1974), the holder of risky corporate bonds can be treated as being an owner of risk-free bonds who has issued put options to the holder of the firm's equity. Based on this theory the so-called structural model of default was developed which is extensively used to analyze corporate bond spreads. ${ }^{1}$ This model offers both a natural economic understanding and an endogenous clarification of credit default allowing applications of option pricing methods.

Another method for modeling credit risk is known as the reduced-form approach, essentially developed by Jarrow and Turnbull (1995), Duffie and Singleton (1999) and Duffee (1999). Compared to the structural models, reduced-form models are more flexible and therefore default risk can to some extent play a bigger role in the pricing of corporate bonds. While the earliest studies have only been able to explain less than half of the variation in credit spreads, leading to the emergence of the so-called "credit spread puzzle", ${ }^{2}$ more recent analyses in this field such as Chen et al. (2009), Feldhütter and Schaefer (2018), Chen et al. (2018) are explaining variance in credit spreads very well and could lead to resolving the credit spread puzzle.

There is a vast body of empirical literature on corporate bond yield spreads, though most of these analyses focus on the US corporate bond market. Prior empirical work can be found in Longstaff and Schwartz (1995) and Duffee (1998). Longstaff and Schwartz (1995) use monthly data for industrial, utility and railroad corporate bond yields for the period from 1977 to 1992 . They regress changes in credit spreads on proxies for two factors: Changes in the 30-year Treasury yield as a proxy for the changes in the interest rate and the returns on industrial, utility and railroad stock indices as a proxy for the return on the underlying assets. These two factors have good explanatory power and both are negatively related to credit spreads. Duffee (1998) focuses on the differences between callable and non-callable bonds and uses monthly data on investment grade corporate bonds from January 1985 through March 1995 to examine how yield spreads vary with changes in the level and slope of the Treasury term structure. He measures the slope with the spread between the 30-year constantmaturity Treasury yield and the 3-month Treasury bill yield and shows that the relation between yield spreads and the slope of the Treasury term structure is also generally negative. Furthermore, although considering various maturity and ratings combinations, only the inclusion of the level and slope of the Treasury term structure can explain (a little less than) $20 \%$ of the variation in the average credit spread.

Elton et al. (2001) are the first to analyze tax effects on changes in corporate bond credit spreads. ${ }^{3}$ Compared to government bonds, corporate bonds have to offer a higher pre-tax

\footnotetext{
${ }^{1}$ Structural models were further investigated and developed by, among others (see the literature overview in Huang 2010), Black and Cox (1976), Longstaff and Schwartz (1995), Collin-Dufresne and Goldstein (2001) and more recently by Chenet al. (2009), Huang and Huang (2012), Dötz (2014) and Feldhütter and Schaefer (2018).

${ }^{2}$ See, for example, Amato and Remolona (2003), Christensen (2008) and Goldstein (2010) for further discussion of the credit spread puzzle.

${ }^{3}$ We exclude tax effects in this study.
} 
return to yield the same after-tax return, since corporate bonds are subject to state and local taxes on interest payments while government bonds are not subject to these taxes. Indeed, they show that taxes account for a considerable portion of the differential between corporates and treasuries, but still a large part of the credit spread remains unexplained. However, using a model with the Fama-French factors (Fama and French (1993)), they find that as much as $85 \%$ of the unsolved spread can be interpreted as being a return for bearing systematic risk. To them, this is clear evidence that credit spreads contain a risk premium required for bearing systematic risk, which is above and beyond the expected loss from default. A subsequent study by Liu et al. (2009) underpin the findings of Elton et al. (2001) that taxes and systematic risk premiums are important factors determining credit spreads in US corporate bond market.

Collin-Dufresne, Goldstein, and Martin (Collin-Dufresne et al. 2001) likewise confirm the finding of Elton et al. (2001). They study the credit spread changes on a monthly basis for 688 bonds from 261 different issuers over the period between July 1988 and December 1997. They additionally control for various liquidity variables, asset volatility, nonlinear effects and the return on the S\&P 500 amongst other essential financial and macroeconomic variables, and still they are able to explain only about $25 \%$ of the variation in the credit spread changes. Interestingly, the residuals from these regressions are highly cross-correlated, and a principal component analysis implies that they are mostly driven by a single common factor. This common systematic factor is likely not firm-specific but an aggregate factor common to all corporate bonds, liquidity premium may be one such factor. Following up on the work from Collin-Dufresne et al. (2001), Campbell and Taksler (2003) analyze the US corporate bond market from February 1995 to December 1999 focusing on the effects of equity volatility on corporate bond yields. Their results suggest that volatility can explain as much of the cross-sectional variation in yields as credit ratings can.

From a theoretical point of view it is anticipatory that for a less liquid asset, investors would demand higher expected returns as a compensation for the liquidity risk (Amihud and Mendelson (1986)). The most utilized measure for estimating liquidity is the bid-ask spread, however the spread is not always available for all bonds or for all time periods. Unlike other studies (e.g. Chakravarty and Sarkar (1999), Schultz (2001) and Hotchkiss and Ronen (2002)) which use the trading volume and bid-ask spread as measures of liquidity, Collin-Dufresne, Goldstein, and Martin (Collin-Dufresne et al. 2001) find only weak evidence for a liquidity premium in the corporate bond yield spread. This suggests that their measures of liquidity (the spread between on- and offthe-run Treasuries, swap spreads, and the frequency of quotes versus matrix prices in the Warga database) may simply be inadequate to capture this factor.

Using a data set of 999 investment grade euro denominated corporate bonds, Houweling et al. (2005) provide strong evidence of priced liquidity in the euro corporate bond market. Using a four-variable model to control for interest rate risk, credit risk, maturity and rating differences between bonds, they find that for eight out of nine liquidity proxies ${ }^{4}$ the null hypothesis that liquidity risk is not priced is rejected. In their study, in contrast to Elton et al. (2001), tax effects are not included.

\footnotetext{
${ }^{4}$ Liquidity proxies used are: issued amount, listed, euro, on-the-run, age, missing prices, yield volatility, number of contributors and yield dispersion.
} 
Longstaff et al. (2005) use weekly data on corporate bond prices for 68 US firms during the period from March 2001 to October 2002 to investigate the role of credit default swaps in explaining changes in credit spread. Using credit default swaps allows to directly measure the size of the default and non-default components in corporate yield spreads. They find that default component accounts for the majority of the credit spread across all ratings, which is in contrast to the results from previous studies. On the other hand, their results indicate that the default component does not explain the entire corporate credit spread. Using different interpretations of liquidity, ${ }^{5}$ they find that bond-specific illiquidity measures are important in explaining cross-sectional differences, while market-wide measures of liquidity explain a sizeable portion of the common variation in all corporate yield spreads, which is clearly consistent with the evidence in Collin-Dufresne et al. (2001). In contrast to Elton et al. (2001), they find only weak support for the hypothesis that the nondefault component is due to tax effects.

Chen et al. (2007) investigate bond-specific liquidity effects on the yield spreads using a battery of liquidity measures covering 4000 US corporate bonds over a 9-year period from 1995 to 2003. Spanning both investment and speculative grade categories, they find the persistence of a strong explanatory power of liquidity for both categories, but it is more pronounced for speculative grade bonds. Moreover, consistent with Longstaff et al. (2005), they find inconsistent statistical evidence of a tax effect. However, in contrast to Longstaff et al. (2005) and Campbell and Taksler (2003), they find little evidence of the importance of either the outstanding principal amount in explaining bond liquidity nor of an equity volatility effect in explaining bond yield spreads. Bond-specific and macroeconomic liquidity effects are the subject of many subsequent studies, which confirm the result that the liquidity premium is an important determinant of expected bond returns; see e.g. Lin et al. (2011). Analyzing recent financial crises, Dick-Nielsen et al. (2012) and Friewald et al. (2012) find that the effect of illiquidity increases dramatically with the onset of the subprime crisis particularly for non-investment grade bonds, confirming the hypothesis of "flight-to-quality" in periods of financial distress. Using a regime-switching model, Acharya et al. (2013) confirm these results, suggesting the existence of time-varying liquidity risk of corporate bond returns conditional on episodes of flight to liquidity.

Not surprisingly, the majority of empirical analyses focus on the US corporate bond market. Nevertheless, there is ongoing work on euro and sterling denominated bonds. Krylova (2016) uses a data set of 5267 individual investment grade euro denominated bonds covering the period from January 1997 to February 2013. Using a general-tospecific estimation technique, she was able to confirm that all credit spread determinants suggested by theoretical and empirical analyses are important for the common factor in corporate bond yield spreads, affecting all bonds identically. She shows that before 2007, the rating effect was the most important driver of corporate bond yield spreads, while the recent episode of the financial crisis and market turmoil was characterized by an increased cross-country and cross-industry heterogeneity. The size and the diffusion of the country effects increased significantly starting from 2010. Moreover, she finds that the impact of the sovereign debt crisis on the changes in

\footnotetext{
${ }^{5}$ Longstaff, Mithal, and Neis (2005) use the following liquidity proxies: bid-ask spread, notional amount outstanding, age of the bond, time to maturity and 2 dummy variables; one for bonds issued by financial firms and one for bonds issued by highly rated firms.
} 
sovereign and corporate ratings led to a break-up of the existence of country ceilings for corporate bond ratings in all countries in her sample, except for Germany and the Netherlands. Klein and Pliszka (2018) use broad market indices for AA- and BBBrated euro denominated bonds over the sample period between January 2003 and February 2015, on a monthly basis. They analyze whether the relationship between corporate bond spreads and their underlying systemic risk factors changes simultaneously over time. Using a Markov switching model with time-varying transition probabilities, they find that in times of market stress, the linkage between bond prices and fundamentals is much stronger than in normal periods and that the crisis regime tends to be longer lasting particularly in the case of BBB-rated bonds.

Leake (2003) focuses on the relationship between credit spreads on sterling corporate bonds and the term structure of UK interest rates. He uses daily price quotes for the period January 1990 to December 1998 to examine the empirical relationship between credit spreads on A- and Aa-rated sterling corporate bonds and the level and slope of the UK yield curve. He distinguishes between 3 duration categories, namely 'short' ( 0 to 4 years), 'medium' (4-8 years) and 'long' (8-12 years). In contrast to Longstaff and Schwartz (1995) and Duffee (1998), he finds no consistent significant relationship between sterling credit spreads and the term structure of the UK interest rates when using daily prices and only a weak relationship when using weekly prices. His results suggest that credit spreads on investment grade sterling corporate bonds have also been driven by factors other than default risk. Boneva et al. (2018) investigate the announcement effect of the Bank of England's Corporate Bond Purchase Scheme (CBPS) from August 2016 (purchases of up to $£ 10$ billion of corporate bonds) on credit spreads. To identify the announcement effect of the CBPS, they employ a difference-in-differences approach assuming that the spreads of eligible and ineligible bonds followed comparable trends before the policy announcement. They find that the CBPS reduced spreads of eligible bonds by 13-14 bps compared to foreign currency bonds issued by the same set of firms but by only $2-5$ bps compared non-eligible sterling corporate bonds. However, due to spillover effects, these results should be interpreted as lower bound.

\section{Data description}

In this section, we present the data used for estimating corporate bond yield spreads in the UK and the EA. We use daily data for the period from January 2013 to March 2018.

A key aspect of our work is to analyze the impact of Brexit on an economy as a whole and on diverse economic sectors. For this reason and some further advantages that using broad indices entails (see Klein and Pliszka (2018)), we choose to use broad market indices rather than single bond data. We use iBoxx indices on corporate and government bonds for the UK and EA, respectively, provided by IHS Markit. Sovereign bond indices contain data on yield, maturity and market value. In addition, corporate bond indices report data on the economy, economic sector, business sector and rating. In our analysis, we include indices on the economy as a whole, two diverse economic sectors (financial and non-financial) and seven business sectors (banks, insurance, financial services, chemicals, industrial goods and services, automobiles and parts and utilities). All analyzed sectors were selected for both systematic and pragmatic reasons. We explore a range of five different time-bands relating to the remaining maturity, namely $1-3$ years, $3-5$ years, $5-7$ years, $7-10$ years and 


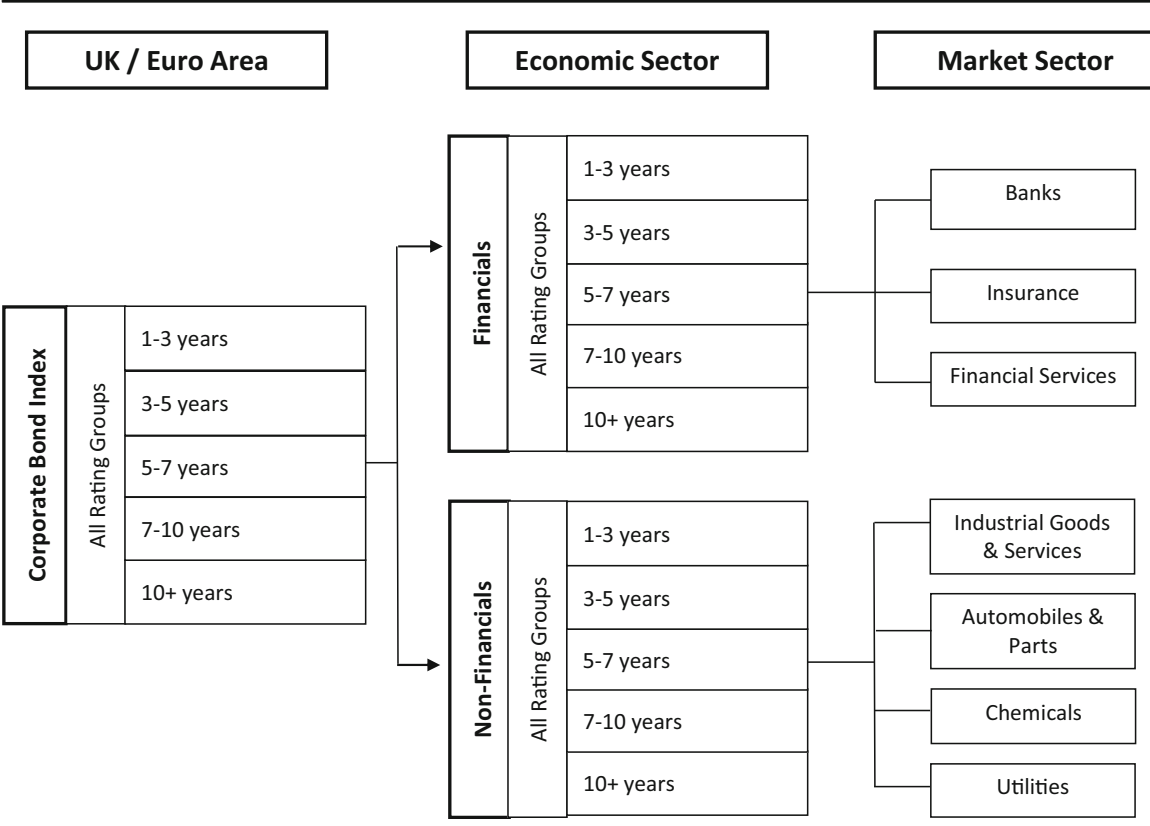

Fig. 1 An overview of credit spreads. Source: own representation

$10+$ years. We choose to take indices for all rating groups combined to capture the corporate bond market as a whole. The credit spread in the respective country $\mathrm{j}$ is defined as the difference between a corporate bond yield with a maturity of up to $\mathrm{m}$ and a benchmark government bond yield with a maturity of up to $\mathrm{m}$. Figure 1 presents an overview of the estimated credit spreads. All data relating to bonds have been obtained from Datastream.

Following the argumentation in ECB (2014), we decided to apply the OIS 3-month rate $\left(\right.$ ois $\left._{j, t}\right)$ as a proxy for a risk-free interest rate. ${ }^{6}$ In order to account for the slope of interest rate curve, we include term spread ( trisk $_{j, t}$ ) in our estimations, which is calculated as a difference between ten- and two-year benchmark government bond yields. lrisk $_{j, s, t}$ represents the liquidity premium. In the absence of bid-ask data, we follow the approach of Schuknecht et al. (2010) and use the size of a debt issue discounted by yield of corresponding index. fwdswap ${ }_{j, t}$ is the 5-year forward on a 5year swap rate in the UK and the EA, respectively. When estimating corporate bond yield spreads representing the economy as a whole, we use the return indices of the FTSE 100 and of the Euro Stoxx 50, as a proxy for return on equity. Return indices of FTSE financials and FTSE non-financials as well as Euro Stoxx financials and Euro Stoxx non-financials are used by estimation of particular economic and market sectors in the UK and EA, respectively. We include $u$ svix $x_{t}$ in all regressions, which represents implied volatility of the S\&P 500 index. All above data are obtained from Datastream.cds $s_{j, t}$ is credit default swap on the UK and EA. Credit default swap data on UK are obtained from Datastream. Credit default swap data for the EA is calculated

\footnotetext{
${ }^{6}$ We also include the squared level of the risk-free interest rate to account for potential nonlinear effects due to convexity (see Collin-Dufresneet al. (2001)). Since the variable has no statistical significance in any of our specifications, we excluded it from our model.
} 
as the sum of GDP-weighted credit default swaps for each member country, excluding Luxemburg and Greece. Luxemburg is excluded due to an absence of data whereas Greece is excluded to avoid the bias of an extremely high and volatile credit default swap. GDP data are extracted from Eurostat and credit default swap data on EA member countries are obtained from Datastream. globav $v_{t}$ represents global investors' risk aversion and is calculated as the difference between the yield of US corporate BBB bonds and the 3-month Treasury rate. Corresponding data are extracted from the Federal Reserve Bank of St. Louis.

It is noteworthy that the dominant maturity range in the UK corporate bond market is $10+$ years, while in the EA corporate bond market the more dominant maturity range is the medium term 3-5 years; after the EU referendum, the share of the 7-10 years maturity range has slightly increased but still remained relatively small (see Figs. 2 and 3, Appendix).

\section{Econometric analysis}

\subsection{Event study methodology}

The choice of corporate bond yield spread determinants employed in our analysis is largely based on previous work in this field. We estimate the following regression model applying the ARMA Maximum Likelihood (ML) method, using a GaussNewton algorithm, over the period from 1 January, 2013, to 30 March, 2018:

$$
\begin{aligned}
& \Delta C S_{j, s, m, t}=\alpha+\gamma \text { brexit }_{t}+\beta_{1} \Delta \text { ois }_{j, t}+\beta_{2} \Delta \text { fwdswap }_{j, t}+\beta_{3} \Delta \text { lrisk }_{j, s, t}+\beta_{4} \Delta \text { trisk }_{j, t}+\beta_{5} \Delta c d s_{j, t} \\
& +\beta_{6} \Delta \text { stockrtn }_{j, s, t}+\beta_{7} \Delta \text { usvix }_{t}+\beta_{8} \Delta \text { globav }_{t}+\beta_{9} \operatorname{ar}(1)+\beta_{10} m a(1)+\varepsilon_{t}
\end{aligned}
$$

where $\Delta C S_{j, s, m, t}$ is our dependent variable of interest and represents the daily change of the credit spread in country $\mathrm{j}$, for sector $\mathrm{s}$ and remaining maturity $\mathrm{m}$. The credit spread in the respective country $\mathrm{j}$ is defined as the difference between a corporate bond yield with a maturity of up to $\mathrm{m}$ and a benchmark government bond yield with a maturity of up to $\mathrm{m}$. The vector brexit $_{t}$ is our independent variable of interest and is an event-dummy variable which is associated with the announcement of the referendum result. This dummy variable takes the value of one on 24 June, 2016, and zero elsewhere. In other specifications, an additional 16 Brexit-related events are included. In principle, Brexit is associated with lower expected future GDP growth rates due to lower aggregate productivity and hence lower expected firm profits. We suspect that aggregate productivity will decline due to increasing barriers to trade in goods and services, to labor and to capital mobility. Lower future firm earnings will lead to a weakening of firm values. A decreasing firm value is associated with an increase of a firm's default probability. Moreover, imported intermediate goods and services will get more expensive due to higher import tariffs. This will lead to higher production costs and hence lower expected profit prospects. Thus, a firm's default probability will rise. According to the dividend discount model of Gordon and Shapiro (1956), expectations about future effects induced by Brexit-related news will immediately affect financial assets and hence credit spreads. To sum up, we hypothesize that Brexit-related news is associated with increasing credit spreads. 
Moreover, in other specifications we split our Brexit events into good Brexit news and bad Brexit news by reading to the Financial Times thoroughly as we suspect that not all Brexit-related news items in our event list are associated with rising credit spreads. ${ }^{7}$ There may be some items of Brexit-related events news which lead to declining spreads because this news might implicate that Brexit will not occur or that its impact on the respective economy might not be as severe as predicted. We have identified nine bad Brexit news events and eight good Brexit news events.

The variable ois ${ }_{j, t}$ reflects the three-month OIS rate in the UK and euro area, respectively. We add ois $_{j, t}$ into our baseline specification in order to control for the impact of an increasing risk-free rate on credit spreads. An increase of the risk-free rate should affect credit spreads negatively because higher interest rates are associated with an increasing risk-neutral drift of the firm value process (Longstaff and Schwartz (1995)). Generally a higher drift leads to a lower risk-neutral probability of default and thus to declining credit spreads. Furthermore, by including ois $s_{j, t}$ into our regressions we also control for the impact of conventional monetary policies conducted by the Bank of England and the European Central Bank on the credit spreads, respectively.

fwdswap ${ }_{j, t}$ is a 5-year forward on a 5-year swap rate in the UK and EA, respectively. A forward interest rate swap is a bilateral agreement in which two parties agree to swap the difference between a fixed interest rate and a flexible interest rate on a set date in the future with predefined terms. A forward swap can therefore be understood as an interest rate swap starting at a defined future date (for example, one may wish to enter into a 5year swap 5 years from the present date). Investors use forward swaps to cover the future expected risk of changes in interest rates. An increase of the forward swap rate may imply investors' expectations about higher short rates in the future, which leads to a decrease in credit spreads. From a different point of view, higher expected future short rates could suggest a positive indication of future overall economic health, which again results in lower credit spreads. To sum up, we expect that the variable $f w d s w a p_{j, t}$ has a negative impact on our dependent variable of interest.

The variable $l r i s k_{j, s, t}$ captures the impact of liquidity risk on the credit spreads. In general, investors have to be compensated for holding less liquid assets. This implies lower prices for less liquid bonds which, in turn, leads to higher bond yields and therefore to higher yield spreads (Longstaff et al. (2005), Chen et al. (2007)). In this paper, we use the discounted size of a debt issue as a proxy for liquidity risk premium (Schuknecht et al. 2010). We suspect that the size of a debt issue has a negative impact on the credit spread.

The variable trisk $_{j, t}$ represents term spread and controls for the impact of the slope of the interest rate term structure on credit spreads. The term spread is defined as the difference between the 10-year benchmark government bond yield and the 2-year benchmark government bond yield. The term spread could be used as an indicator for overall economic health (Duffee (1998), Collin-Dufresne et al. (2001)). An increase of the term spread reflects a stronger economy and hence an increasing term spread is associated with declining credit spreads. Moreover, an increase of the term spread may be associated with higher expected short-term rates and hence with decreasing credit spreads. To sum up, we expect that the variable $t_{r i s} k_{j, t}$ has a negative impact on our dependent variable of interest.

\footnotetext{
${ }^{7}$ See Korus and Celebi (2018) for a detailed description of the classification of good and bad news.
} 
The corporate credit default swaps (CDS) provide an almost ideal way of directly measuring the size of the risk-neutral default component (credit risk premium plus expected default loss) in corporate yield spreads (Longstaff et al. 2005). In order to approximate the credit default risk we use the corresponding CDS premium on government bonds $\left(c d s_{j, t}\right)$, due to limited access to corporate CDS data. Nonetheless, recent research in this field has verified a strong theoretical and empirical evidence for risk transfer from sovereign to corporate (see, e.g., Augustin et al. (2016), Bedendo and Colla (2015), Acharya et al. (2014)). Thus, we believe that government CDS are still a good proxy for credit default risk in credit spreads. We expect that increasing CDS spreads are associated with rising credit spreads.

The variable $\operatorname{stockrtn}_{j, s, t}$ is the respective benchmark stock market index from the UK and the euro area, respectively. In this study, we use the return indices of the FTSE 100 and the Euro Stoxx 50. Equity markets reflect up-to-date information and are good indicators of the overall state of the economy (Longstaff and Schwartz (1995), CollinDufresne et al. (2001)). Thus by including benchmark stock market indices into our baseline specification, we try to capture the influence of changes in the business climate on credit spreads. An increase in the value of a firm's equity should decrease the probability of default and therefore we expect a negative impact on credit spreads.

Furthermore, we include the implied volatility of the S\&P 500 index $\left(u\right.$ svix $\left._{t}\right)$. This variable captures the impact of global financial market uncertainty on our dependent variable of interest. Given expected profits, the volatility of firm value hurts bondholders, because it increases the probability of default (Campbell and Taksler 2003). Thus, volatility should drive up the bond yields and increase credit spread ceteris paribus. Hence, we expect that an increase of the US VIX leads to rising credit spreads.

The variable globav $_{t}$ represents global investors' risk aversion and is calculated as the difference between the yield of US BBB corporate bonds and 3-month US Treasury bond yields. Higher global risk aversion generally leads to a higher demand for safe assets due to a flight-to-quality response (Schuknecht et al. (2010), Klose and Weigert (2013)). Hence, in times of global financial turmoil or greater uncertainty, government bond yields decline and corporate bond yields rise. Thus, we expect a positive impact of globav $_{t}$ on credit spreads in the UK and EA corporate bond markets.

In other specifications, we also control for the impact of macroeconomic news on credit spreads by including the United Kingdom series and the euro area series of the Citigroup economic surprise index (CESI). Furthermore, we check for the influence of the Bank of England's (NSMPBOE) European Central Bank's (NSMPECB) nonstandard monetary policy announcements on our dependent variables of interest. Moreover, we include an $\mathrm{AR}(1)$ term $(\operatorname{ar}(1))$ and $\mathrm{MA}(1)$ term $(m a(1))$ into our baseline specification. ${ }^{8}$ The term $\varepsilon_{t}$ represents the error term.

The variables used in our regressions are defined as follows: Credit spreads, threemonth OIS rates, the 5-year forward swap rates, the term spread, CDS spreads, our measure for general investor risk aversion, and the CESI index are expressed as percentage point changes. The size of a debt issue, benchmark stock market indices,

\footnotetext{
${ }^{8}$ Serial correlation is a common occurrence in time series data because the data is ordered (over time).Therefore, we use Augmented Dickey-Fuller and additionally Breusch-Godfrey Serial Correlation LM Tests to check for it. Since the null hypothsis of no serial correlation could easily be rejected, we include the autoregressive AR(1) and moving-average MA(1) models in the modelling of the conditional mean to account for own previous values and for the current and previous values of an error term.
} 
and the US VIX are expressed in percentage rates of change. Table 1 summarizes the description of the explanatory variables and gives the expected sign of each.

\subsection{Estimation results}

Firstly, we investigate whether the announcement of the Brexit referendum result had an impact on UK credit spreads for bonds with a remaining maturity of 1-3 years, 35 years, 5-7 years, 7-10 years and 10+ years, including all rating groups, respectively. We expect that the release of the referendum result is associated with increasing credit spreads in the UK. Our benchmark specification also includes the UK three-month OIS rate, the UK five-year-five-year $(5 y / 5 y)$ forward swap rate, the liquidity premium, the change in 10-year minus 2-year UK government bond yields, the CDS premium on UK government bonds with a maturity of up to five years, the return index of the FTSE 100 , the volatility index of the S\&P 500 index, and the global risk aversion variable. ${ }^{9}$ The estimation results are reported in Table 2.

Our estimation results show that the three-month OIS rate, which could be considered as a risk-free rate, has a negative impact on the credit spreads for all bonds. In almost all cases the coefficient of the three-month OIS rate is highly statistically significant. However, the three-month OIS rate does not affect the credit spread for bonds with a maturity of up to 10 year plus. Hence, our findings are consistent with the literature (Longstaff and Schwartz (1995), Collin-Dufresne et al. (2001)), which finds that an increase in drift is associated with a lower risk-neutral probability of default. Furthermore, our results indicate that the $5 y / 5 y$ forward swap rate affects the credit spreads for all bonds negatively. Hence, the coefficient of the $5 y / 5 y$ forward swap rate shows the expected sign. The coefficient is highly statistically significant in all cases. Concerning our proxy for market liquidity, the results show that this variable has a highly significantly negative impact on the corporate bond yield spreads. Hence, our results confirm the findings of Schuknecht et al. (2010).

The slope of the term structure has a statistically significant impact on the credit spread with a remaining maturity of $1-3$ years, $7-10$ years and $10+$ years. We find that an increase of the slope of the term structure is associated with decreasing long-term corporate bond yield spreads, which is in line with theory. However, our results indicate that the slope of the term structure has a highly significantly positive impact on the corporate bond yield spread with a remaining maturity of 1-3 years, which is at odds with theory. Studies investigating the impact of the term structure on credit spreads in US are, however, inconclusive. On the one hand, Pavlova et al. (2015) find a negative relationship between the term structure and corporate bond spreads, while on the other hand, Chun et al. (2014) report a positive correlation. Moreover, our proxy variable for the corporate credit default risk has no statistically significant impact on our dependent variables of interest. Hence, our results indicate that either credit default risk does not play a role in explaining credit spreads in the UK or that our proxy does not really capture corporate credit default risk. If the latter explanation applies, the CDS premium of 5-year UK government bonds should not be correlated with corporate CDS spreads.

\footnotetext{
${ }^{9}$ We also controlled for the impact of macroeconomic news and unconventional monetary policies conducted by the $\mathrm{BoE}$ and the ECB, respectively. However, the results are in line with the benchmark results. These results are available on request.
} 
Table 1 Explanatory variables and expected signs

\begin{tabular}{lll}
\hline Variable & Description & Predicted Sign \\
\hline$\Delta$ ois $_{j, t}$ & Change in risk-free interest rate & - \\
$\Delta$ fwdswap $_{j, t}$ & Change in 5 year forward on a 5 year swap rate & - \\
$\Delta$ lrisk $_{j, \mathrm{~s}, t}$ & Change in size of a debt issued & - \\
$\Delta$ trisk $_{j, t}$ & Change in 10-year minus 2-year benchmark government bond yield & - \\
$\Delta$ cds $_{j, t}$ & Change in credit default swap premium on government bonds & + \\
$\Delta$ stockrtn $_{j, \mathrm{~s}, t}$ & Change in return on respective benchmark stock market index & - \\
$\Delta u$ svix $_{t}$ & Change in implied volatility of S\&P 500 & + \\
$\Delta$ globav $_{t}$ & Change in US BBB corporate bond index minus 3-month US Treasury bond & + \\
\hline
\end{tabular}

Own representation

The return index of the FTSE 100 is statistically significant with the predicted sign. Hence, an improvement of the business climate in the UK is associated with a declining credit spread for all bonds. Furthermore, our results show that higher global financial market uncertainty is associated with increasing credit spreads in the UK. The coefficient of the S\&P 500 volatility index is statistically significant in all estimations. The global risk aversion variable shows a positive impact on our dependent variables of interest which is in line with our expectations. The coefficient of the global risk aversion variable has a statistically significant impact on the corporate bond yield spread with a remaining maturity of 1-3 years and 10+ years, respectively.

Our Brexit-event dummy has a statistically significant positive impact on almost all dependent variables of interest. ${ }^{10}$ We find no statistically significant impact of our Brexit-event dummy on the credit spread with a maturity of 1-3 years. Hence, our empirical results confirm our expectation that Brexit-related news items are associated with increasing corporate bond yield spreads in the UK because market participants expect lower future firm earnings due to Brexit. However, our empirical results indicate that only the announcement of the referendum result had an influence on the credit spreads in the UK. Our estimation results suggest that Brexit-related events, other than the announcement of the result of the Brexit referendum, have no statistically significant impact on corporate bond spreads in the UK.

Next, we differentiate between the financial and the non-financial economic sectors in order to analyze more specific sector-related effects of our Brexit-event dummy. In Tables 3 and 4 we report the impact of our Brexit dummy on the corporate bond yield spreads in the financial sector and the non-financial sector, respectively. Our results suggest that the announcement of the referendum result positively affected credit spreads in both the financial and the non-financial sector. The impact only lacks significance in the case of financial bonds with a maturity of 3-5 years and non-

\footnotetext{
${ }^{10}$ One should note that the statistical significance of the coefficient on a binary dummy does not only depend on its "explanatory power" concerning that single observation of the dependent variable, but also on the sample length of the data. For example, if one would broadly extend the sample length of the study, the contribution of the dummy variable to the total prediction error could be substantially lower and might even become statistically insignificant even if the estimated coefficient has not changed.
} 


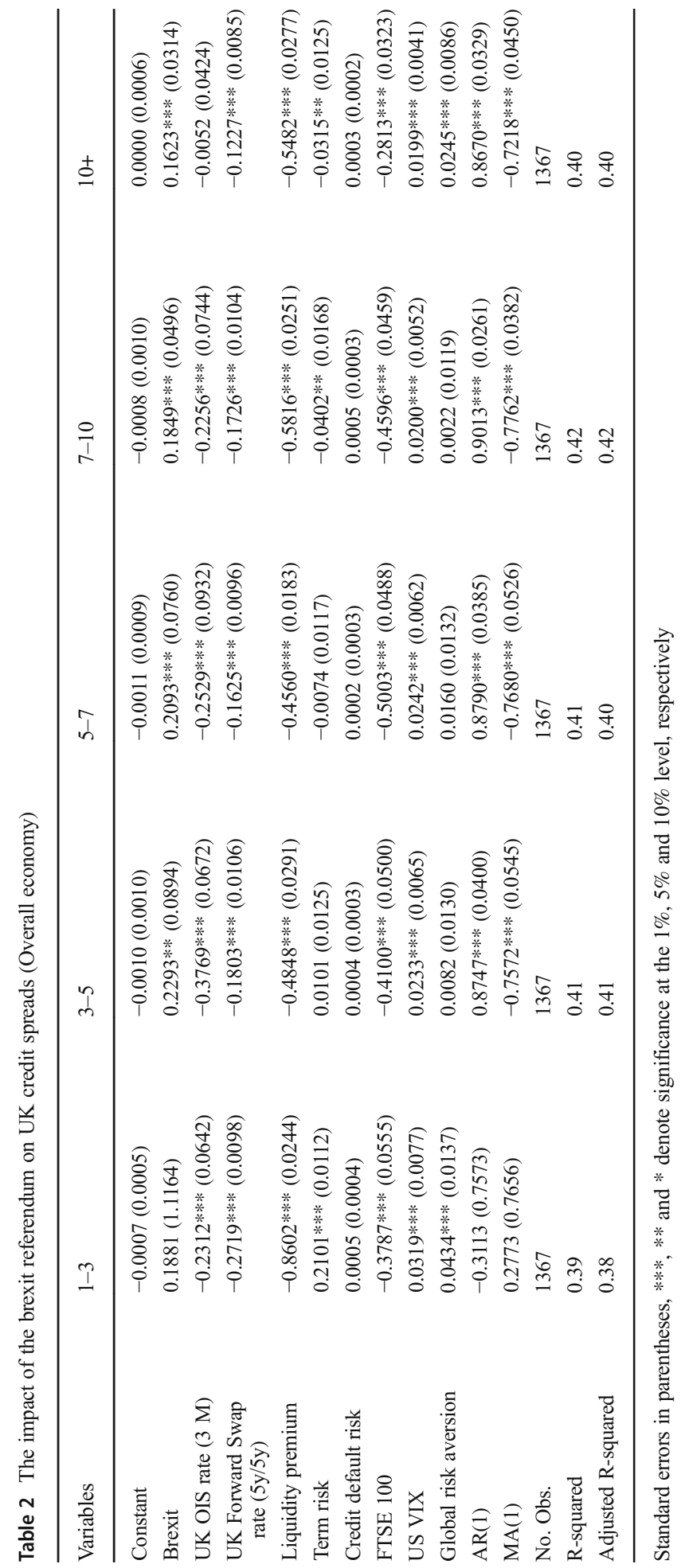




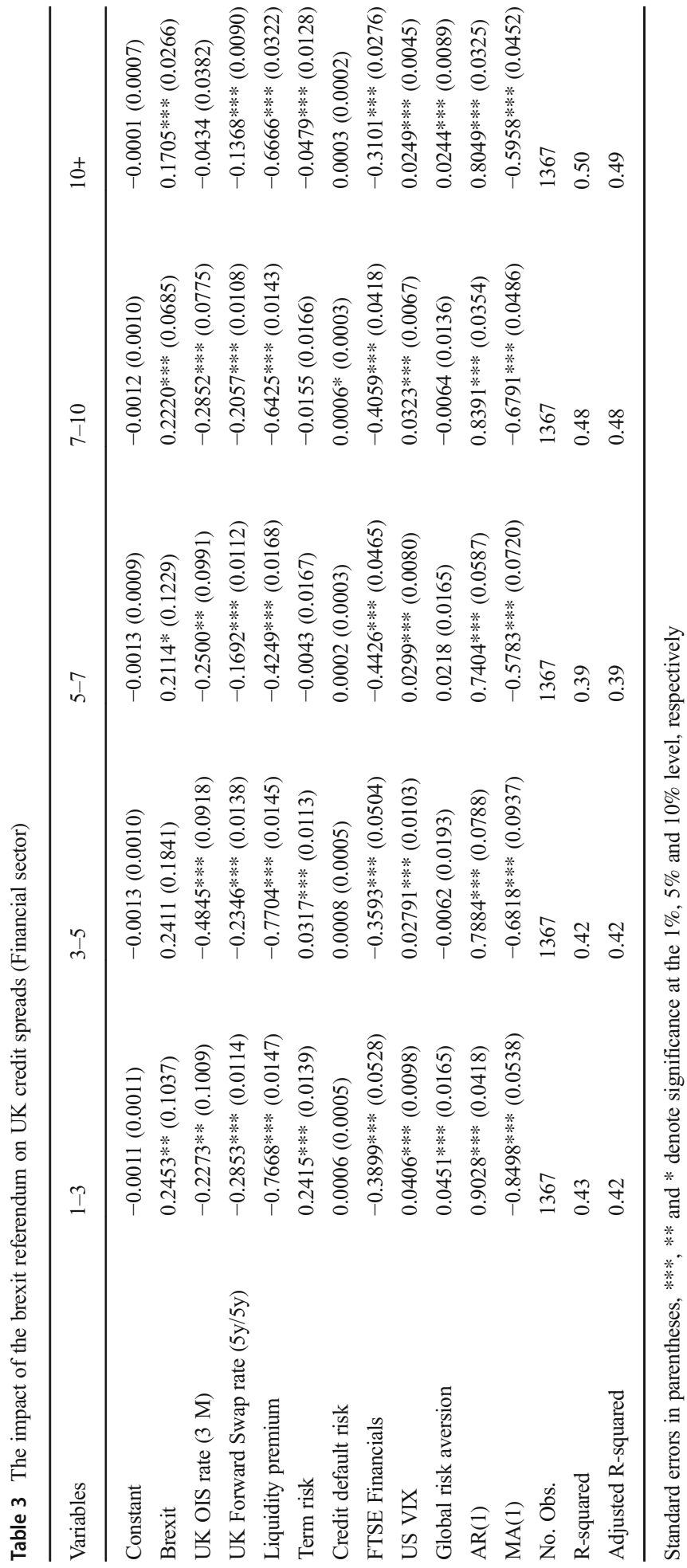




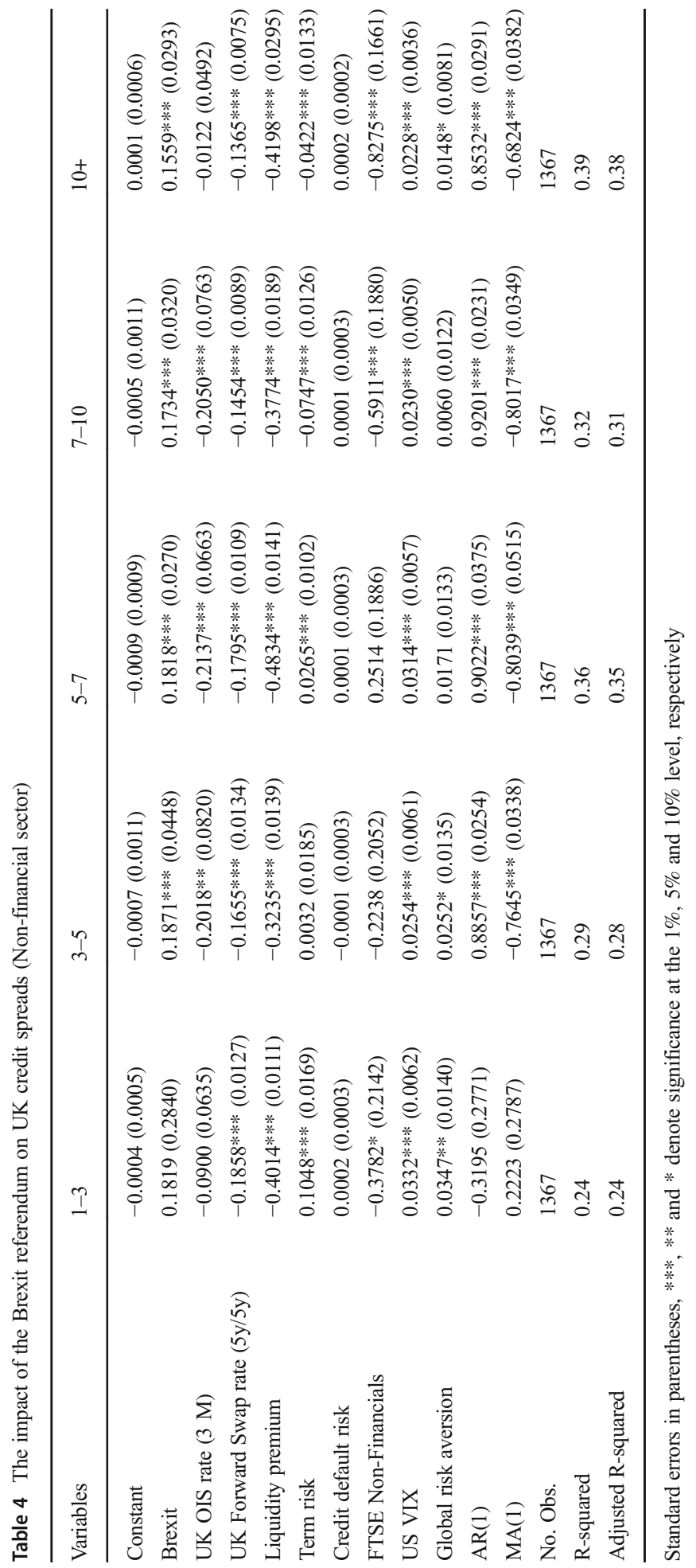


financial bonds with a maturity of 1-3 years. Hence, the financial and the non-financial economic sectors were influenced by the Brexit referendum.

Moreover, we find that the three-month OIS rate negatively affected both the financial corporate bond yield spreads and the non-financial corporate bond spreads. We also find that the $5 y / 5 y$ forward swap rate negatively influenced corporate bond yield spreads in the financial and the non-financial sectors, respectively. Hence, the $5 \mathrm{y} /$ $5 y$ forward swap rate affects credit spreads in the financial and the non-financial sectors in the same way. Our proxy for the liquidity premium has a highly statistically negative impact on all dependent variables of interest. Furthermore, the absolute size of the coefficients and the statistical significance of our measure of liquidity risk suggest that this variable is the most relevant systematic factor. The slope of the term structure affects credit spreads in the financial and the non-financial sectors, respectively. However, in a few cases, the coefficient of our term structure variable shows no statistical significance in both Tables 3 and 4 .

Furthermore, our estimation results reported in Tables 3 and 4 suggest that the 5-year UK sovereign CDS spread plays only a minor role in explaining corporate bond yield spreads in both the financial sector and the non-financial sector. The coefficient of the return index of the FTSE Financials index in Table 3 displays a highly statistically significant impact on credit spreads in the financial sector. As predicted by theory, the estimated signs are always negative. The return index of the FTSE Non-Financials index has a significant impact for parts of the analyzed corporate bond yield spreads in the non-financial sector (see Table 4). Moreover, the volatility index of the S\&P 500 index has a positive significant impact on the analyzed portfolios. The global risk aversion variable shows a positive impact on our dependent variables of interest which is in line with theory. Sometimes the coefficient shows a negative sign but in these cases the global risk aversion variable has no significant impact.

Next, we examine whether the announcement of the Brexit referendum result had an effect on euro area (EA) credit spreads for bonds with remaining maturities of 13 years, 3-5 years, 5-7 years, 7-10 years and 10+ years, including all rating groups, respectively. On the one hand, we want to find out whether corporate bond yield spreads in the euro area were affected by Brexit-related events, and on the other hand we want to see whether EA credit spreads or UK corporate bond yield spreads were most effected by Brexit-related news. We expect that UK credit spreads were more strongly affected by Brexit events than EA corporate bond spreads. The estimation results for the impact of the announcement of the Brexit referendum results on EA corporate bond yield spreads are reported in Table 5 .

Our estimation results suggest that the announcement of the referendum result is associated with increasing credit spreads in the EA. The coefficient of our Brexit-event dummy shows a positive sign and is partly statistically significant. Our Brexit-event dummy has a statistically significant impact on 1-3 years, 3-5 years, and 10+ years credit spreads in the euro area, respectively.

Concerning the impact of short-term interest rates on EA credit spreads, we find a negative impact, as predicted by theory, of the three-month OIS rate on corporate bond yield spreads in the EA. However, we find that the three-month OIS rate positively affects $10+$ years EA credit spreads but the coefficient is not statistically significant. Furthermore, the $5 \mathrm{y} / 5 \mathrm{y}$ forward swap rate has a statistically significant impact on credit spreads in the euro area. In almost all regressions, the coefficient of the $5 \mathrm{y} / 5 \mathrm{y}$ forward 


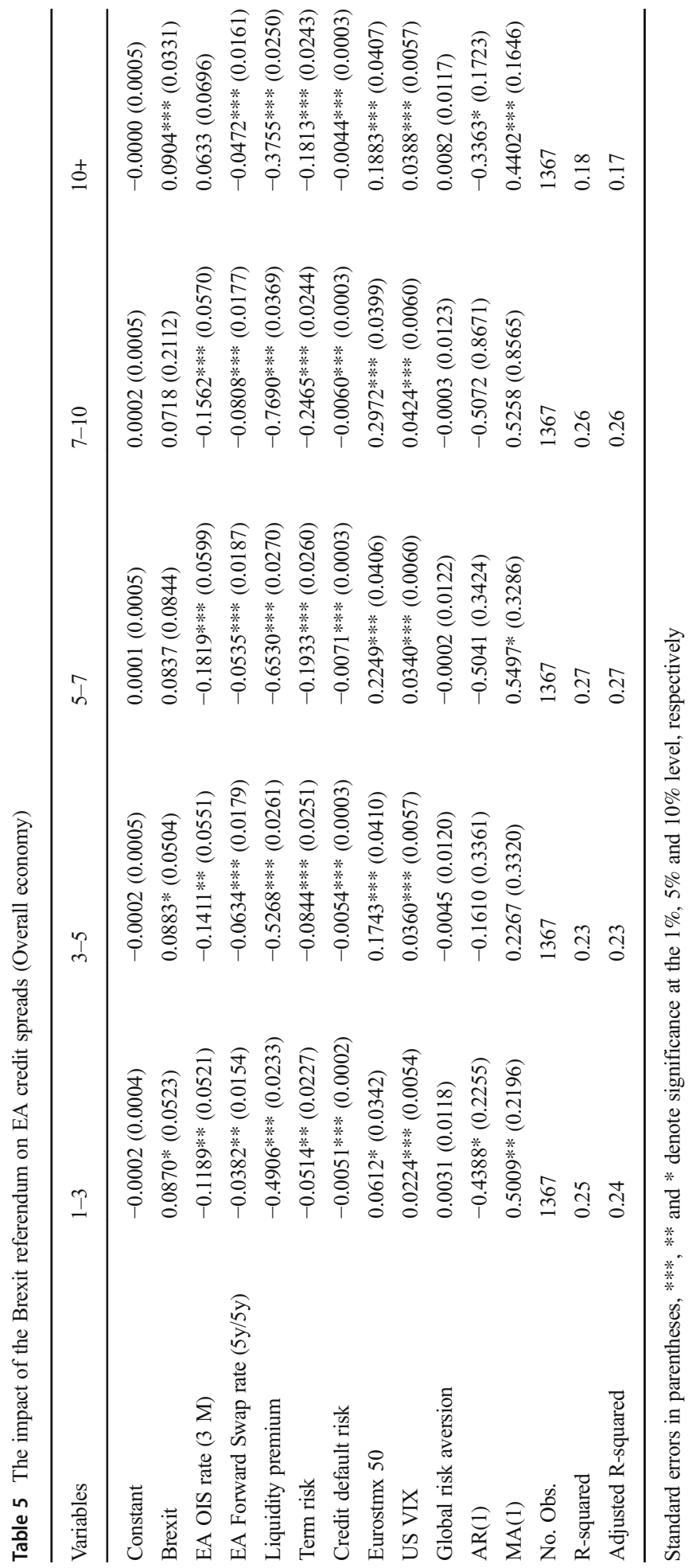


swap rate is highly statistically significant. As expected, the $5 y / 5 y$ forward swap rate negatively influences our dependent variables of interest. Our proxy for market liquidity is found to have a statistically negative impact on EA credit spreads. The slope of the term structure shows a statistically negative impact on credit bond yield spreads in the euro area. Hence, higher expected future short rates or rather an improvement of economic health increased credit spreads in the euro area.

Our results, displayed in Table 5, also suggest that rising sovereign CDS premia lead to lower corporate bond yield spreads in the euro area. Hence, our empirical findings concerning the impact of the 5-year sovereign CDS spread on EA credit spreads stand in contradiction to theory. We suspect that heterogeneity within the euro area plays an important role, due to different countries' creditworthiness. On the one hand, increasing sovereign CDS premia may be associated with decreasing credit bond spreads in safe haven countries like Germany and the Netherlands, on the other hand rising sovereign CDS premia could be associated with rising credit spreads in countries like Spain and Portugal (Klose and Weigert (2013)). Furthermore, we find that the return index of the Eurostoxx 50 has a significantly positive impact on EA credit spreads. This puzzling result might be explained by the role of the Eurostoxx 50 as a measure for financial market uncertainty (Deutsche Bundesbank (2017)). The coefficient of the volatility index of the S\&P 500 displays a significantly positive influence on corporate bond yield spreads in the euro area. Moreover, our empirical results show that our proxy for global risk aversion is not statistically significant.

Next, we examine the impact of our Brexit-event dummy on corporate bond yield spreads in the financial sector and the non-financial sector in the euro area, respectively. Estimation results are reported in Tables 6 and 7. Our results indicate that the financial sector was more strongly affected by the announcement of the Brexit referendum result than the non-financial sector. Our Brexit-event dummy variable has a statistically significant impact on all credit spreads in the financial sector. The announcement of the referendum result is associated with increasing corporate bond yield spreads in the financial sector. Moreover, estimated coefficients display the same magnitude for all maturities. In contrast to that, our Brexit-event dummy has a limited impact on credit spreads in the non-financial sector. The statistical significance of the dummy variable is rather weak. Our Brexit-event dummy has a statistically significantly impact only on $10+$ years credit spreads in the non-financial sector. The coefficient shows a positive sign and hence the announcement of the referendum result has led to rising 10+ year's credit spreads in the non-financial sector. Furthermore, our results reported in Tables 6 and 7 indicate that the financial sector in both the United Kingdom and the euro area was affected by the announcement of the Brexit referendum result. However, our empirical results suggest that credit spreads in the UK non-financial sector were influenced by our Brexit-event dummy whereas corporate bond spreads in the EA non-financial sector were hardly effected by the referendum result. This does not necessarily mean that Brexit will have no effect on the credit spread in the non-financial sector in the EA corporate bond market. This conclusion would be misleading since we estimate direct short-term effects. Quite the contrary, it is plausible to assume that Brexit would have both medium- and long-term effects on corporate bond yield spreads in the nonfinancial sector in the EA once the financial sector is affected due to spillover effects and a strong cross-interlocking between those two sectors.

Furthermore, we find that the three-month OIS rate has a statistically significant impact on three of five credit spreads in the financial sector and on four of five spreads in the non- 


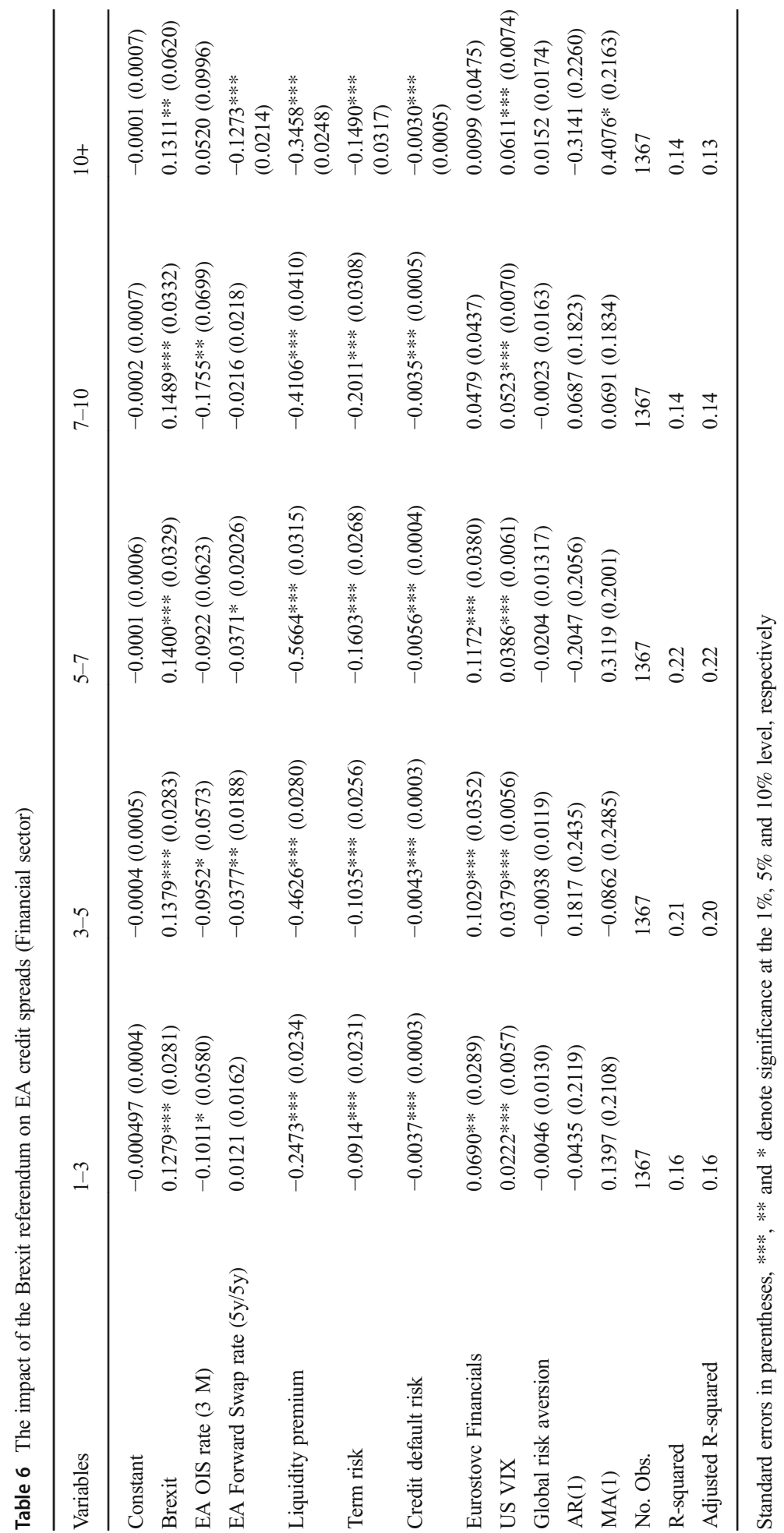




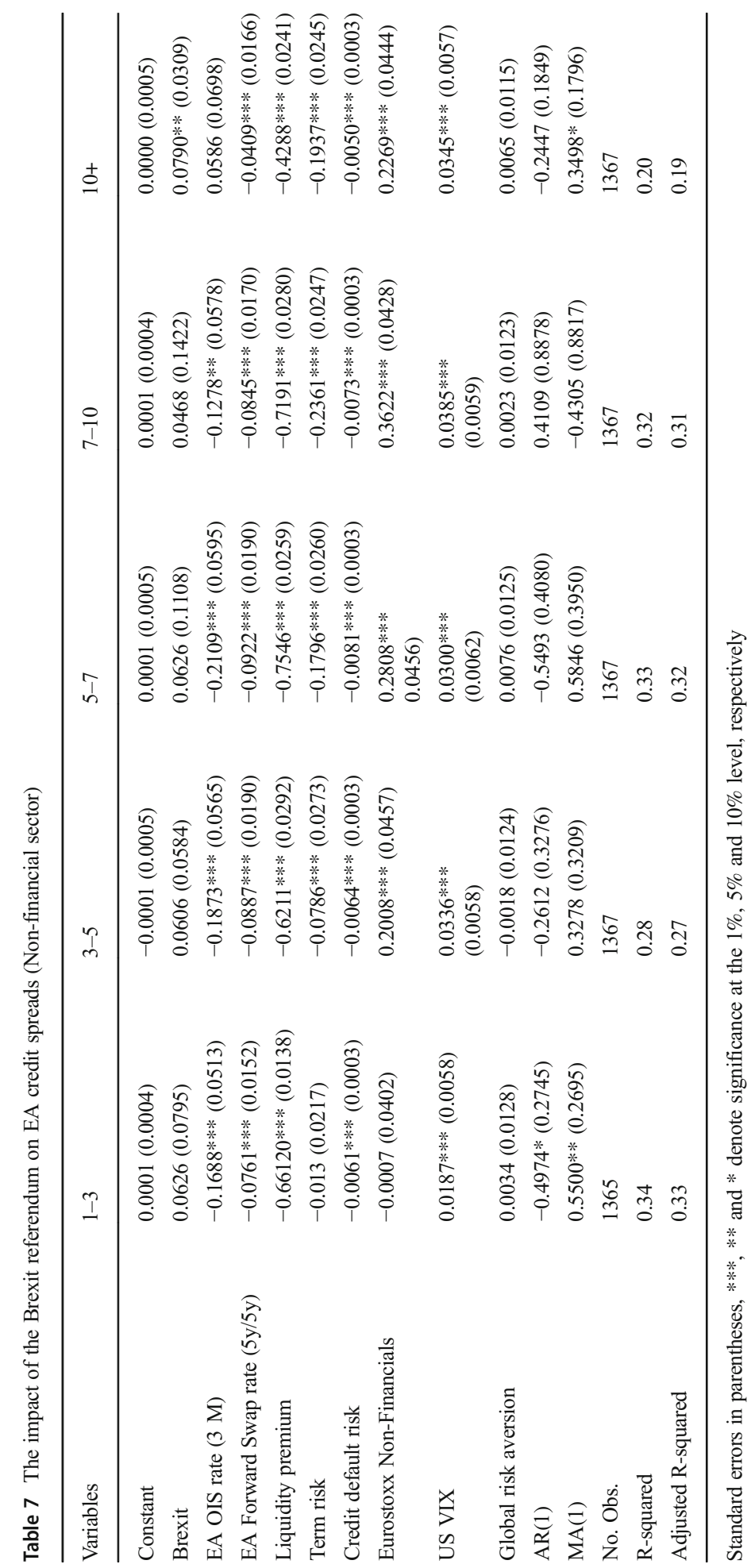


financial sector. Whenever the impact of the risk-free rate on credit spreads turns out to be statistically significant, the coefficient shows a negative sign. The $5 y / 5 y$ forward swap rate has a significant negative impact on corporate bond yield spreads in the EA non-financial sector and is less significant in the EA financial sector. Our proxy for liquidity risk has a highly statistically significant impact on credit spreads in both the financial sector and the non-financial sector, respectively. Moreover, we find that the slope of the term structure plays an important role in explaining the change of the credit spreads in the financial and non-financial sectors. Our default risk variable displays a significantly negative impact on credit spreads in the financial and non-financial sector. The return index of the Eurostoxx Financials has a statistically significant impact only on short- and medium-term spreads in the financial sector. The coefficient of the return index of the Eurostoxx Financials shows a positive sign, which is at odds with theory. Almost all credit spreads in the non-financial sector were statistically significantly affected by the return index of the Eurostoxx NonFinancials. The coefficient also shows a positive sign. Furthermore, credit spreads in the financial and non-financial sectors were positively influenced by the volatility index of the S\&P 500. We also find that the coefficient of the global risk aversion variable turns out to be statistically insignificant.

Additionally, we estimate the impact of the Brexit referendum result on seven different business sectors to test whether credit spreads from the three financial business sectors (banks, financial services and insurance) and 4 non-financial business sectors (industrial goods and services, chemicals, automobiles and parts and services) react differently. In fact, due to diverse risk conditions in each business sector and given that different business sectors are influenced by macroeconomic instabilities in different ways, we expect to find that credit spread response differ across sectors. Unfortunately, our model provides unstable results. Thus, from the perspective of statistical significance we are not able to deliver final and conclusive compelling evidence on the impact of the Brexit referendum result on specific business sectors. However, this lack of robust results may simply reflect the fact that for analyzing business sectors more specific data on a microeconomic level are required. This holds especially for the EA corporate bond market due to a higher heterogeneity in that market. For the sake of brevity, we present no results here but these are available on request.

\subsection{Additional Brexit-related events}

In this section we study the impact of 16 Brexit-related events, excluding the referendum, on corporate bond yield spreads in the UK and the euro area, respectively. These 16 Brexit-related pieces of news are divided into bad Brexit events and good Brexit events by reading the Financial Times thoroughly. Hence, we create an event dummy which consists of bad Brexit events and a dummy variable which captures good Brexit events. With our event identification strategy we find a total of eight bad Brexit event days and eight good Brexit event days. ${ }^{11}$ We suspect that bad Brexit news are associated with increasing credit spreads in the UK and the euro area, respectively. Concerning the influence of good Brexit news on corporate bond yields in both the UK and euro area we expect that the coefficient sign of the Brexit good news dummy variable is continuously negative. Estimation results are reported in Tables 8 and 9.

${ }^{11}$ The announcement of the referendum result is classified as bad Brexit news. 


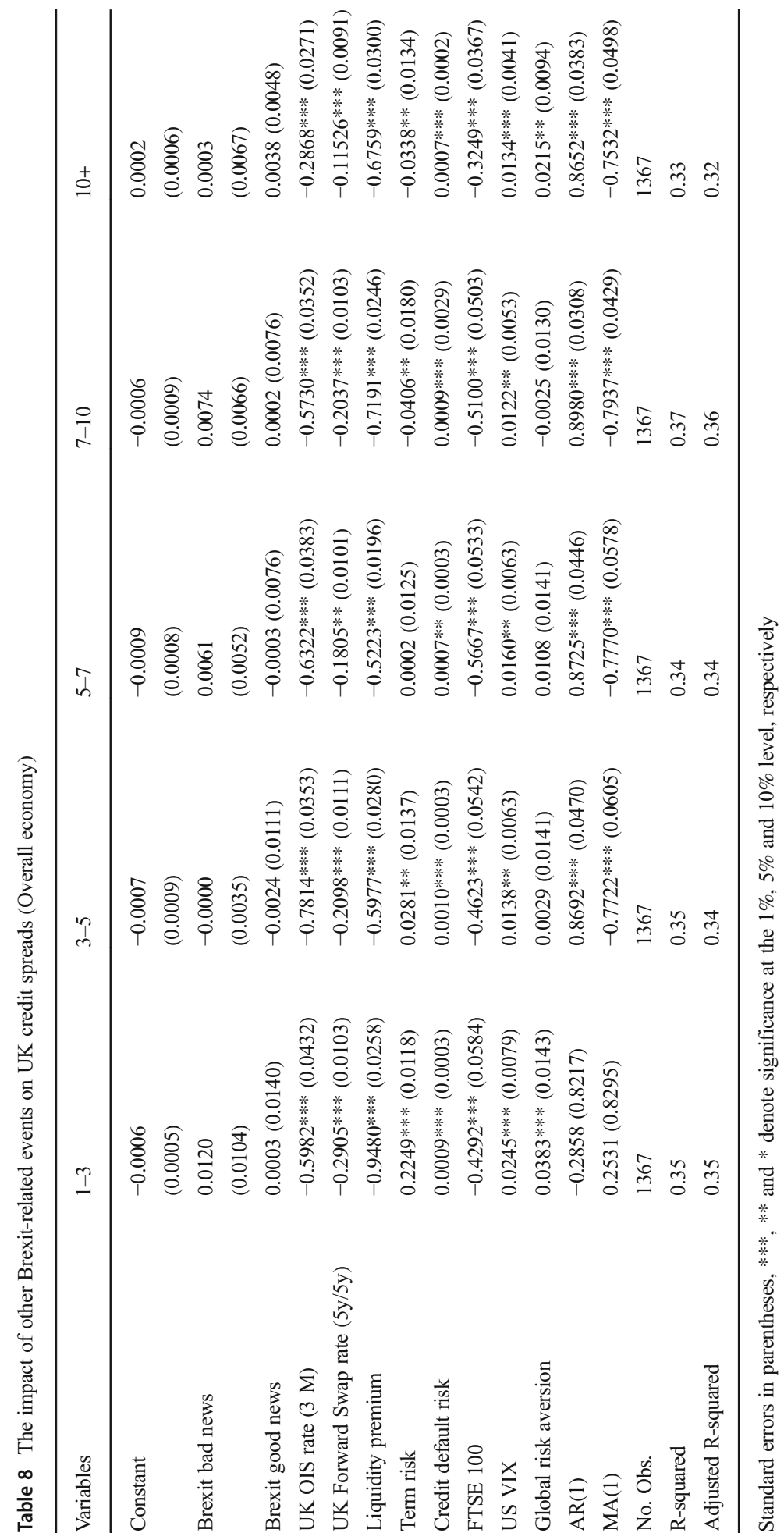




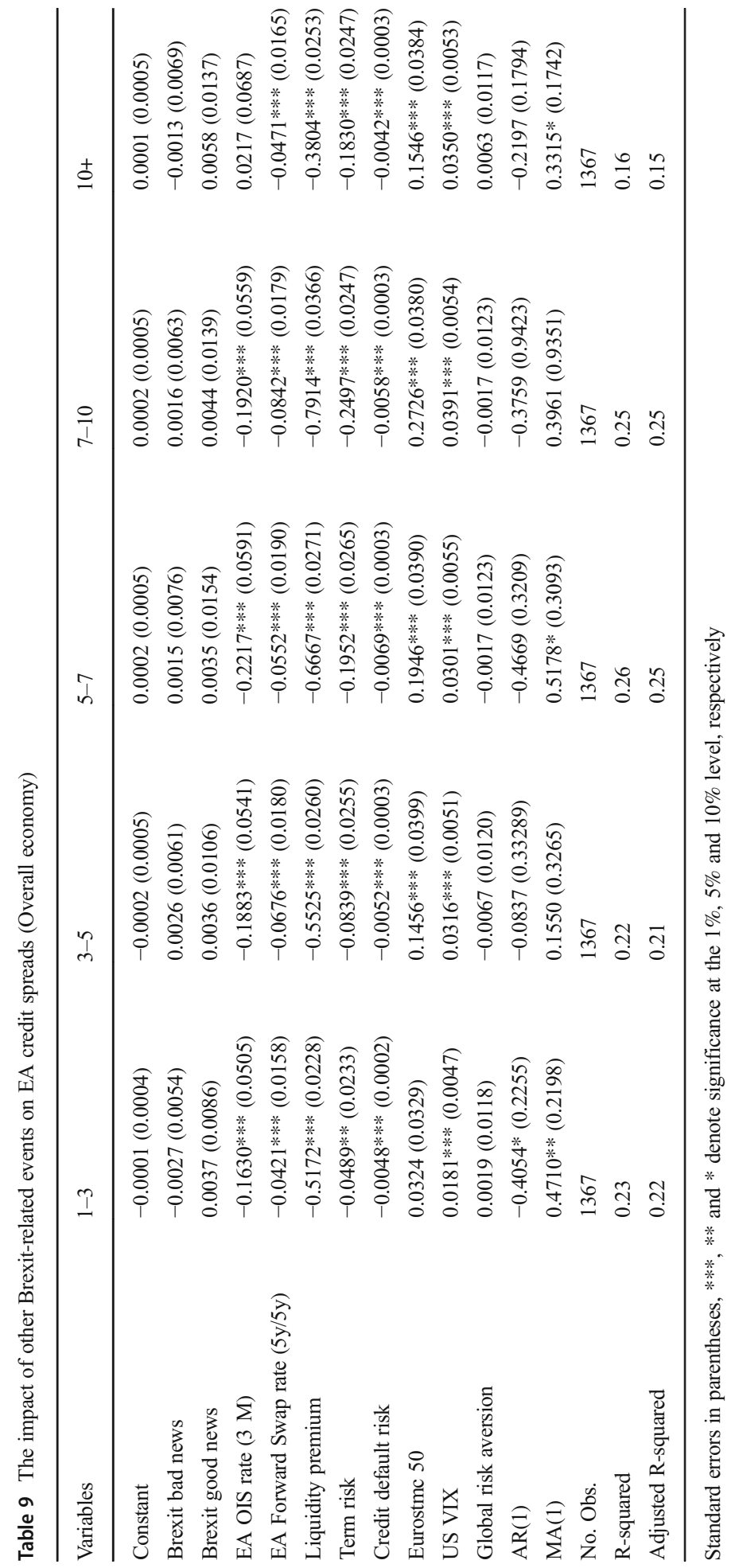


Firstly, we investigate whether bad and good Brexit news has an impact on credit spreads in the UK economy as a whole (see Table 8). Our empirical results suggest that bad Brexit events, excluding the announcement of the referendum result, has no statistically significant impact on corporate bond yield spreads in the UK. Concerning the impact of good Brexit news on UK credit spreads, we find no statistical significance. Thus, our empirical results suggest that good Brexit news has no impact on corporate bond spreads in the UK. Hence, we conclude that only the announcement of the referendum result, and no other Brexit news, has an impact on UK corporate bond yield spreads. ${ }^{12}$

Secondly, we elaborate on the impact of bad news, excluding the announcement of the referendum result, and good news on EA credit spreads, respectively (see Table 9). Our empirical results indicate that bad Brexit news, excluding the referendum, has no statistically significant influence on EA credit spreads. Thus, when removing the main Brexit event from other bad Brexit event days, we find no significant impact on UK and EA credit spreads, respectively. Concerning the influence of good Brexit news, we also find no statistical significance. ${ }^{13}$ Thus, only the announcement of the referendum result itself has an impact on our dependent variable of interest. Hence, it seems that good Brexit news has an impact on neither UK credit spreads nor on EA corporate bond spreads.

\section{Time-varying aspects}

One concern about the estimates in section 4.2 is that they do not take into account the possible time-variation in investors' risk sensitivity and the pricing of risk. It is plausible to assume that the influence of credit spread determining variables changes over time. Prior work on corporate yield spreads has already indicated the possibility of a time varying influence of the determining variables; see, for example, Longstaff et al. (2005). This problem was the subject of ongoing work. Using a Markov regime-switching model, Acharya et al. (2013) and Klein and Pliszka (2018) confirm these findings and moreover are able to show that particularly in periods of stressed market conditions systematic risk factors play a much more important role by determining changes in credit spreads, in the US as well as in EA corporate bond markets. Furthermore, analyzing recent financial crises, Dick-Nielsen et al. (2012) and Friewald et al. (2012) find that in times of financial turmoil the effect of illiquidity increases dramatically.

If the real underlying coefficients are time varying, as several previous studies have shown, then the estimated coefficients in Tables 2, 3, 4, 5, 6 and 7 are potentially inaccurate and may also be misleading in interpreting investor's risk sensitivity and the pricing of risk. Additionally, as shown in section 4.3, only the result of the Brexit referendum has a strong significant impact on corporate yield spreads. All other Brexitrelated events were statistically insignificant. Thus we decided to split our sample in two sub-samples, namely a pre-referendum (January 1st, 2013, to June 23rd, 2016) and post-referendum period (June 24th, 2016, to March 30th, 2018), to allow to consider the potential changing evaluation of the determinants of corporate bond spreads. We

\footnotetext{
${ }^{12}$ We also find that bad Brexit news, excluding the referendum, and good Brexit news have no statistically significant impact on corporate bond yield spreads in the financial sector and the non-financial sector in the UK, respectively.

${ }^{13}$ We also find no statistically significant impact of Brexit-related events, excluding the referendum, on credit spreads in the financial sector and the non-financial sector in the Eurozone, respectively.
} 
follow Friewald et al. (2012) and incorporate a dummy variable for the post-referendum period; hence, our dummy variable takes the value 1 from June 24th, 2016, on. We similarly include interaction terms between the dummy variable and our credit spread determinants for the post-referendum period, with the aim of analyzing whether the changes in credit spreads are more sensitive to our determining variables in times of market turmoil due to altering risk pricing triggered by the Brexit referendum result. We estimate the following regression model:

$$
\begin{aligned}
& \Delta C_{j, s, m, t}=\alpha+\beta_{1} \Delta \text { ois }_{j, t}+\beta_{2} \Delta \text { fwdswap }_{j, t}+\beta_{3} \Delta \text { lrisk }_{j, s, t}+\beta_{4} \Delta \text { trisk }_{j, t}+\beta_{5} \Delta c d s_{j, t} \\
& \quad+\beta_{6} \Delta \text { stockrtn }_{j, s, t}+\beta_{7} \Delta \text { usvix }_{t}+\beta_{8} \Delta \text { globav }_{t}+\left(\text { Brexit }_{\text {Ref.Dummy }) x\left[\gamma_{1} \Delta \text { Ris }_{j, t}\right.}\right. \\
& \quad+\gamma_{2} \Delta \text { fwdswap }_{j, t}+\gamma_{3} \Delta \text { lrisk }_{j, s, t}+\gamma_{4} \Delta \text { trisk }_{j, t}+\gamma_{5} \Delta c d s_{j, t}+\beta_{6} \Delta \text { stockrtn }_{j, s, t} \\
& \left.\quad+\beta_{7} \Delta \text { usvix }_{t}+\beta_{8} \Delta \text { globav }_{t}\right]+\beta_{9} \operatorname{ar}(1)+\beta_{10} m a(1)+\varepsilon_{t}
\end{aligned}
$$

The results for the UK credit spreads (overall economy) are reported in Table 10. We do not observe a statistically significant increase in all of the proxies but there are some noteworthy findings which we would like to highlight. Interestingly, we cannot confirm a "flight-to-liquidity", which was observed by previous studies. Our proxy variable for liquidity has a statistically significant additional impact on the credit spreads in three out of five maturities, however with different sign. The liquidity variable has a negative sign with a maturity of 7-10 years but a positive sign with a maturity of 3-5 years and 5-7 years. This finding restricts our ability to make precise conclusions about the additional impact of liquidity on credit spreads. Although, Acharya et al. (2013) find that in a stress regime the sign of liquidity betas is quite the opposite for investment grade and speculative bonds. In episodes of stressed macroeconomic and financial conditions, investors are more averse to illiquidity shocks and they respond by switching from illiquid assets, such as speculative bonds, to investment grade bonds which are known to be more liquid. This finding may provide a plausible explanation for our results, since we do not distinguish between different rating categories. This question is beyond the scope of this paper and represents an interesting avenue for further research.

The most pronounced change can be observed for credit default risk. Surprisingly, our proxy variable turned significant and has a highly statistically significant impact on yield spreads in three out of five maturities, namely maturities of 1-3 years, 5-7 years and $10+$ years, and a significance at the $10 \%$ level with a maturity of 3-5 years and 710 years, respectively. Unfortunately, due to limited access to corporate CDS data, we use the corresponding CDS premium on government bonds, which means we are unable to measure the direct impact of corporate default risk. We can measure only the indirect impact of default risk as a consequence of the risk transfer channel from sovereign to corporate. Nevertheless, this is an important result suggesting that default risk plays a more important role in periods of market turmoil. Also our two global variables, global volatility and global risk aversion, point to some interesting developments after the Brexit referendum. First, we record strong statistical significance only with a maturity of $10+$ years and second, for all five different maturities, except for the impact of global risk aversion on credit spreads with a maturity of 7-10 years, the sign has turned and changed into negative. These results indicate that the United Kingdom's 


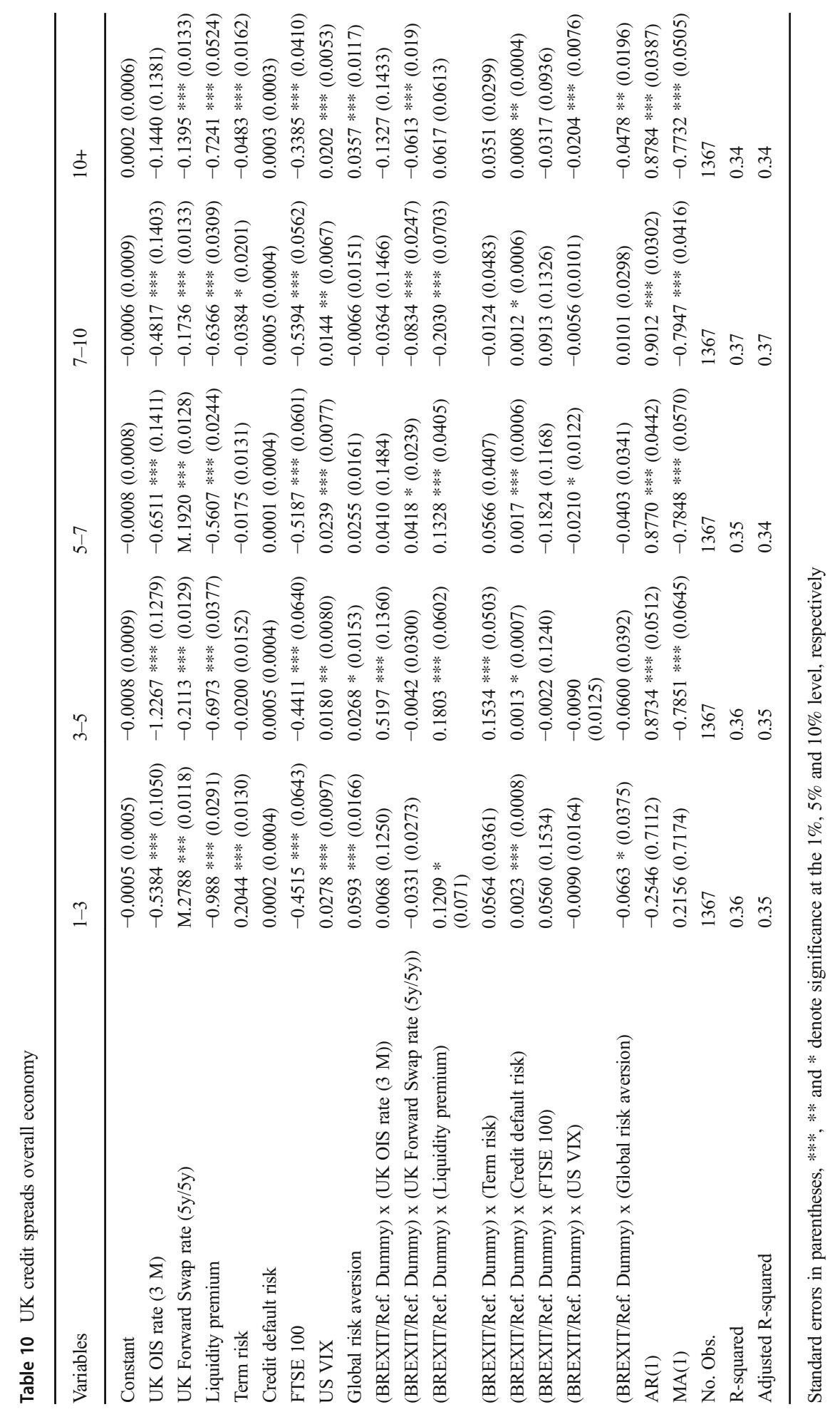


safe haven status was weakening in this period (see, Bernoth and Erdogan (2012)). ${ }^{14}$ This has serious consequences for policymakers when it comes to taking the necessary actions in order to moderate the effects of Brexit and its aftermath.

We now move on to separately examining the financial and non-financial economic sectors in order to analyze more specific sector-related changes in the impact of determining variables on credit spreads in the pre- and post-referendum periods. Not surprisingly, a very similar picture also emerges for the financial and non-financial sectors. Tables 11 and 12 report the results. The findings reveal strong commonalities except for our credit default risk variable. While for the non-financial sector the variable still stays statistically significant for four out of five maturities, namely with a maturity of 1-3 years, 3-5 years, 5-7 years and 10+ years, for the financial sector we observe significance only with a maturity of $1-3$ years and $10+$ years. This finding suggest that Brexit and rising trade barriers with a potential to limit trade with EU - and other nonEU countries - would have a strong negative impact on the productivity and profitability of affected firms in the non-financial sector, an effect that would degrade the credit worthiness of UK firms in this sector and lead to a higher refinancing costs.

Next, we examine whether there were some changes in risk pricing in the EA corporate bond market as a consequence of the Brexit referendum outcome. The results are reported in Table 13. Our proxy for liquidity risk gets a positive sign for four out of five different maturities, namely with a maturity of $1-3$ years, 3-5 years, 5-7 years and 7-10 years which is a somewhat similar development to the UK corporate bond market. We notice a statistically significant increase of our newly introduced variable, the $5 \mathrm{y} / 5 \mathrm{y}$ forward swap rate, which indicates investors' stronger sensitivity to future expected interest rates development and overall economic health. Interestingly, we observe the most evident change once again of the credit default risk variable. In the postreferendum period, our proxy for default risk has a positive sign and is highly statistically significant for all five different maturities. This is strong indication for the risk transfer channel from sovereign to corporate in the euro area countries, especially in times of market turmoil, which was already affirmed by previous studies (see, e.g., Augustin et al. (2016), Bedendo and Colla (2015)). The problem of risk transfer from sovereign to corporate should be of particular importance for the euro area governments, since EA is a heterogeneous union with country ratings ranging from $\mathrm{B}+$ for Greece and BBB for Italy to AA for France and AAA for Germany, so that country risk problems could easily be overlooked and disregarded.

In the same way as before, in the next step we analyze the changes in impact of our determining variables on credit spreads in the pre-referendum and post-referendum periods differentiating between the financial and non-financial sectors. The results are summarized in Tables 14 and 15 . The outcomes confirm the previously observed risk transfer channel which plays an important role by determining credit spreads for the financial as well as for the non-financial sector. Additionally, in reference to the financial sector, the respective benchmark stock market index (Eurostoxx Financials) gets a negative sign, which is consistent with theory, and is highly statistically significant with a remaining maturity of $1-3$ years, 3-5 years, 5-7 years and 7-10 years. This finding indicates that investors pay more attention to the business climate and to

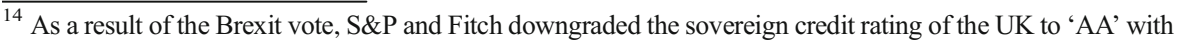
a negative outlook on 27th/28th June, 2016.
} 


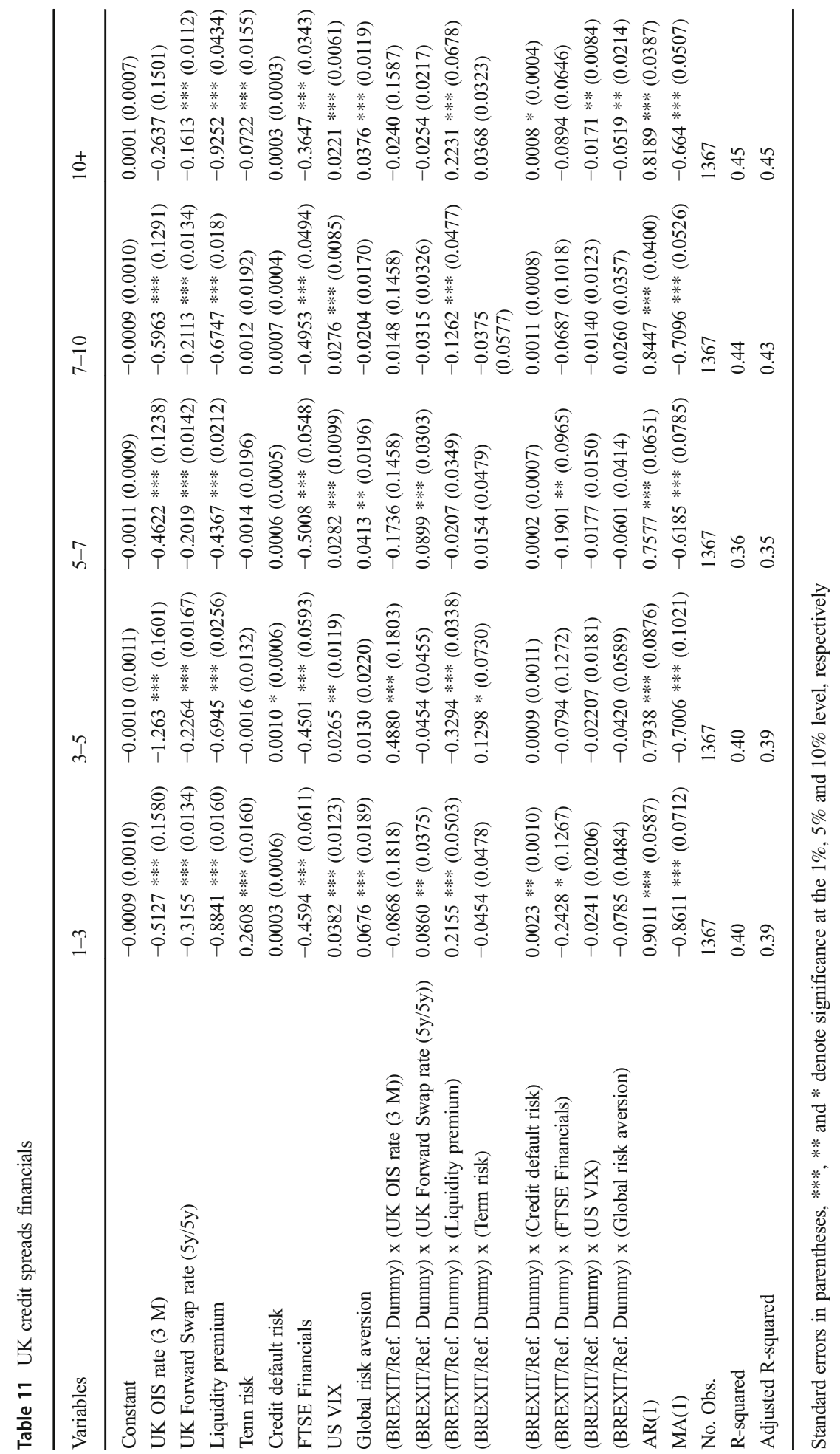




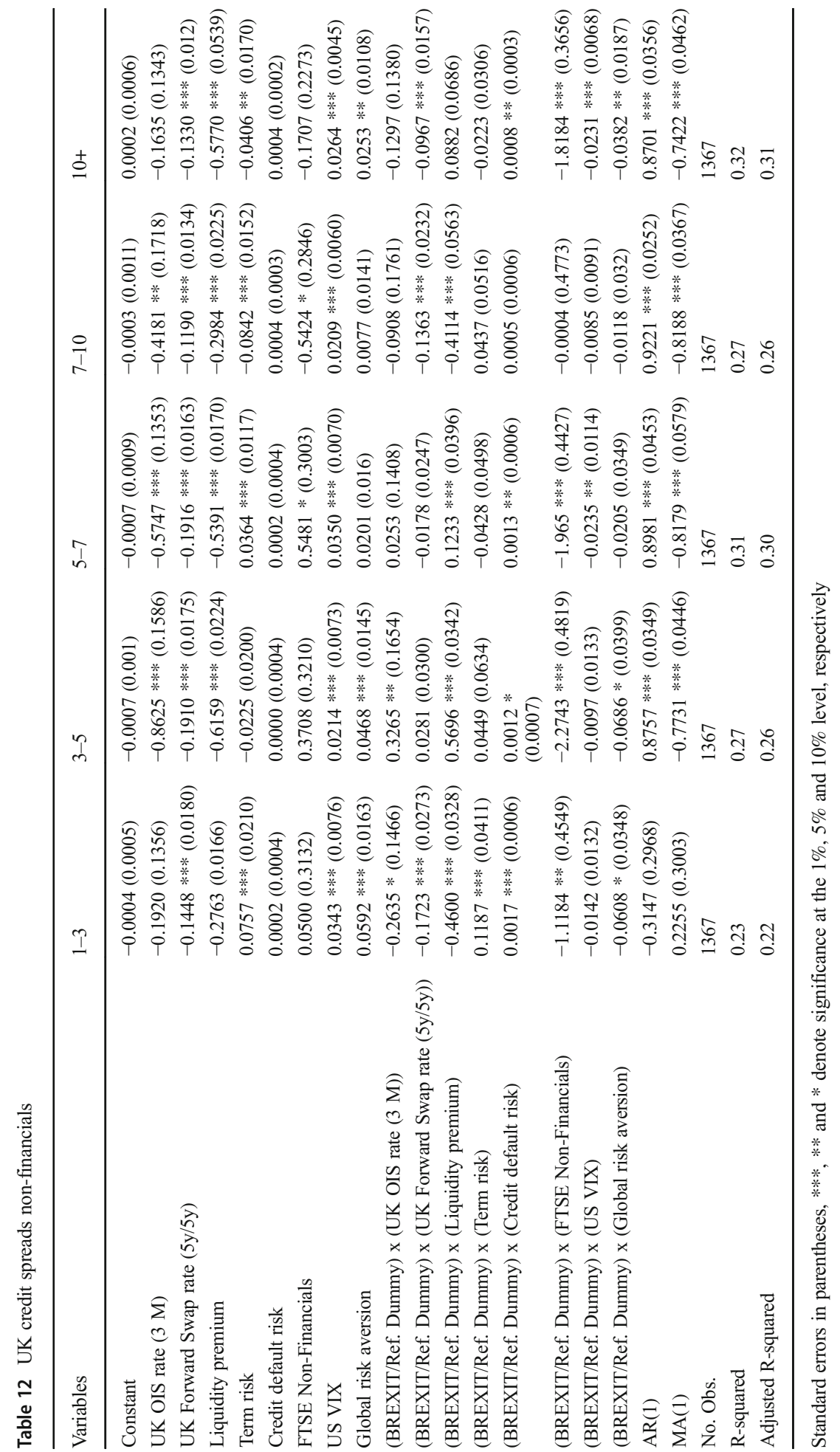




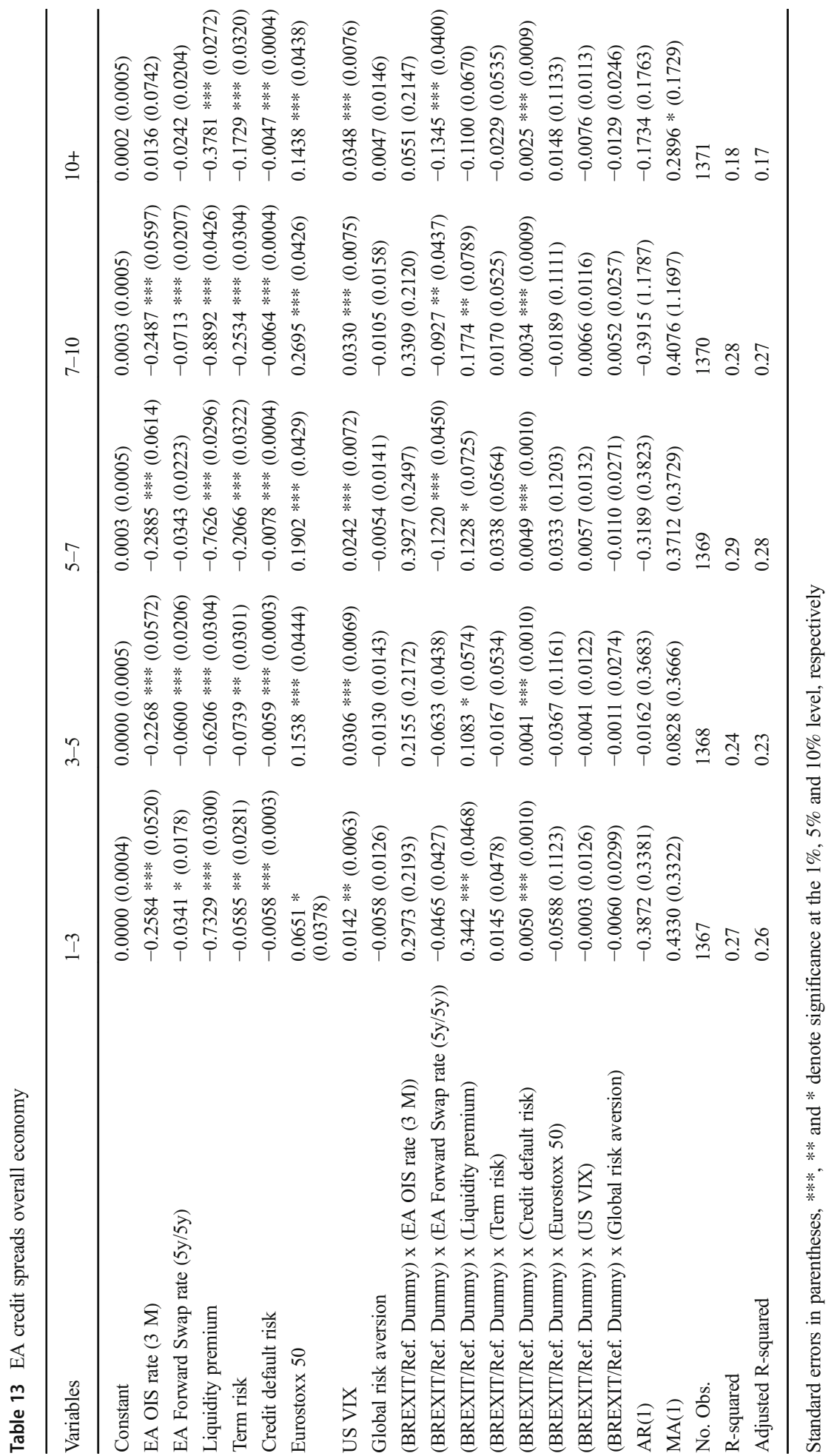




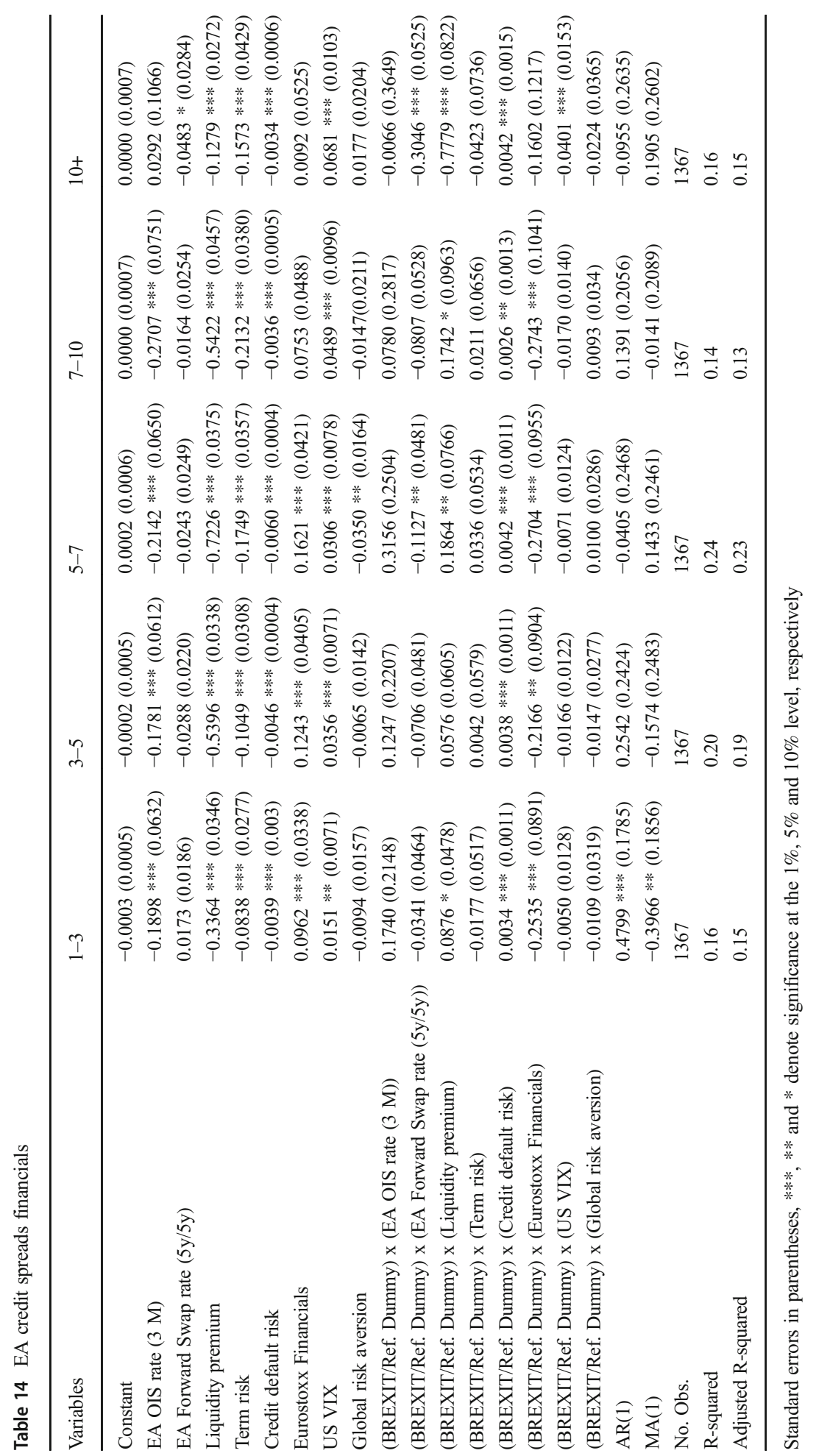




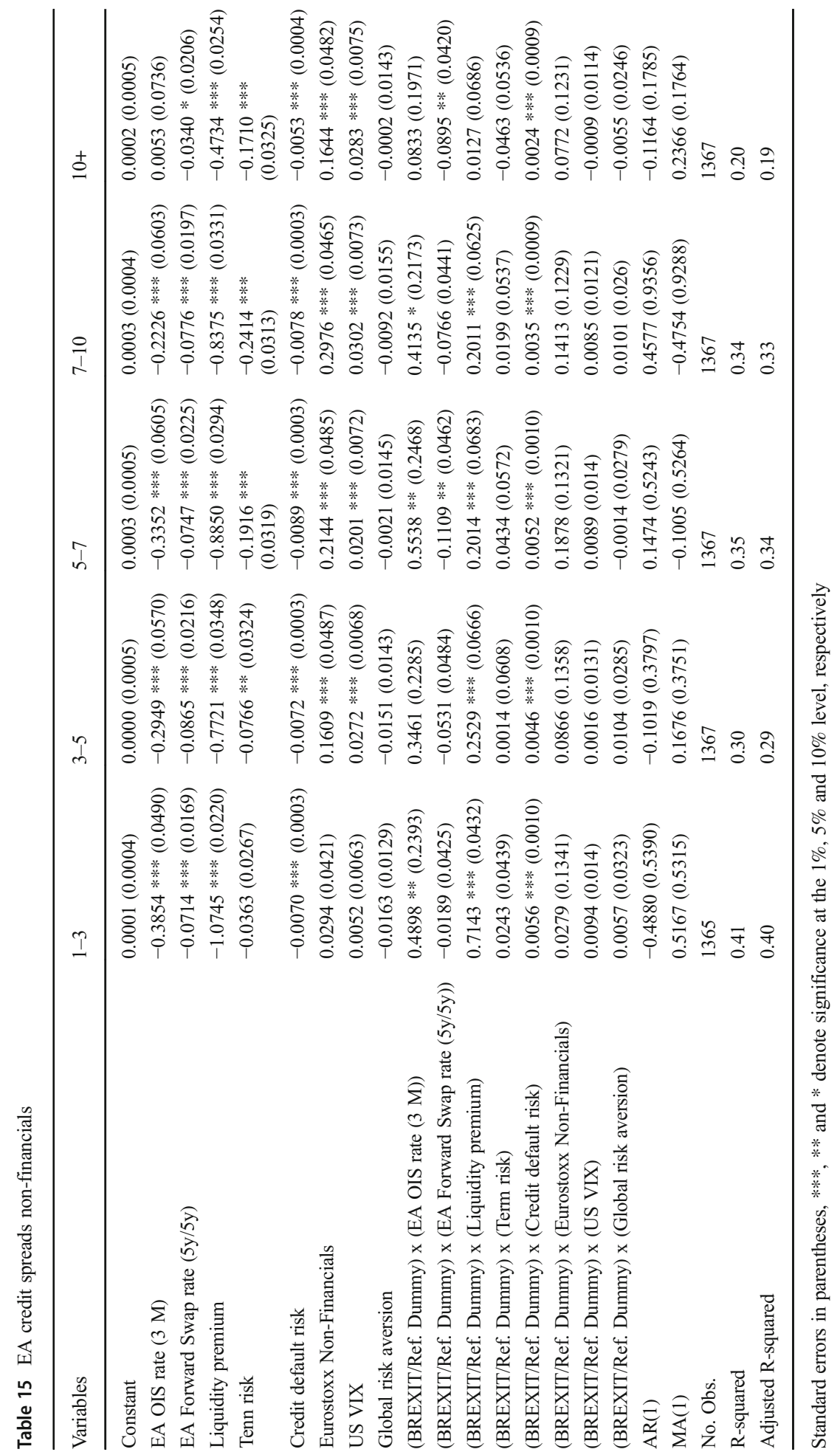


the future expected overall state of economy in the post-referendum period. Concerning the non-financial sector in EA, the corporate bond market liquidity variable has a strong statistically highly significant additional impact on credit spreads, although for all maturities the sign is positive.

Estimating determinants of corporate bond yield spreads in times of market turmoil is of particular interest for governments, companies and investors to illuminate the conditions under which the refinancing of debt is particularly costly and to generate information, if possible, about which variables should be monitored with the intention of possibly reducing refinancing costs. The inconstancy of statistical significance sometimes even involving changes in sign - makes it difficult to recommend which determinant policymakers and companies should monitor to prevent increasing refinancing costs.

\section{Conclusion}

Policymakers and financial economists alike are concerned about the impact of Brexit on future economic developments in the UK and EU27 member countries, respectively. Over the last three years, several issues relating to Brexit and its effects have been analyzed at a theoretical and empirical level. Corporate bond markets are still less liquid than equity or foreign exchange markets, nonetheless they play a very import role for fund-raising from the perspective of companies and are a reliable indicator for risk conditions in the market.

In this paper, we examined the impact of Brexit-related events on the risk conditions in the United Kingdom and euro area corporate bond markets, respectively. The model includes daily spreads data covering the period from January 2013 to March 2018. We consider the major determinants of corporate bond yield spreads, which are largely based on and affirmed by previous studies in this field. An appreciable feature of our analysis is the lead use of forward swap rate data, which has shown a significant importance in almost all our empirical findings indicating that future expected interest rate developments play an important role in determining credit spreads.

A number of important insights about the estimation of credit spreads in the UK and EA corporate bond markets emerges from this study. We show that Brexit-related events had an impact on risk conditions in those two corporate bond markets. However, our estimation results suggest that only the referendum result is associated with increasing corporate bond yield spreads. Additionally, our findings indicate that UK credit spreads were more strongly influenced by the announcement of the result of the Brexit referendum than were credit bond spreads in the euro area. Distinguishing between the financial and the non-financial economic sectors allowed us to analyze more specific sector-related effects of the referendum result. We find that the financial sectors in both the UK and EA were affected by the announcement of the Brexit referendum result. However, the results suggest that credit spreads in the UK non-financial sector were significantly influenced by the Brexit vote whereas corporate bond spreads in the EA non-financial sector were hardly effected by the referendum result.

Furthermore, we split our sample into two sub-samples, namely pre-referendum and post-referendum periods, to allow to consider the potential changing evaluation of the determinants of corporate bond spreads due to altering risk pricing triggered by the 
Brexit referendum result. The results demonstrate that risk perception is rather volatile and can change intensely over time especially in periods of market turmoil. Our findings indicate that the United Kingdom's safe haven status was weakening in the post-referendum period. That brings serious consequences for policymakers when it comes to taking actions necessary to moderate the effects in the aftermath of Brexit. Additionally, we find that the effect of the credit default risk measure is far stronger and plays a significant role in the post-referendum period in both the UK and EA. This finding is of particular importance not only to corporates but also to governments, since we measure the indirect impact due to the risk transfer channel from sovereign to corporates.

Our findings are useful for analyzing further aspects of Brexit and its impact on future economic development. Future research should focus on testing whether the consideration of a different measure of credit worthiness is able to highlight additional aspects of risk conditions in the UK and EA corporate bond markets and changes in them due to the Brexit aftermath, respectively. In addition, an advanced detailed analysis of specific business sectors, for example banks, financial services, automobile etc., would generate even further information of particular interest for corresponding companies in the relevant sectors.

The UK seems to face specific risks in the context of Brexit as risk premiums in corporate bond markets might increase and this could in turn negatively affect the role of the UK as a safe haven. Hence, expected lower capital inflows into the UK imply that investment growth in the UK post-Brexit would be smaller than otherwise which would make restoring high growth in the UK a more difficult task. From this perspective, it is all the more important that the UK government would be able to adopt a consistent macroeconomic policy that helps restore the broad confidence of international investors in the UK corporate bond market.

Naturally, our regression results cannot include the aspect that the relocation of foreign-owned UK-based banks to the Eurozone or other financial centers in the world economy could weaken confidence in the UK bonds market. While some relocation has been visible in 2017/18, the full adjustment process should take several years and thus the implications of the relocation dynamics can be assessed only at a later point in time. If relocation is considerable, the liquidity of UK corporate bonds markets and the sophistication of financial services available in London should be negatively affected. Risk diversification within the UK corporate bonds market might be negatively affected as some market segments might become rather thin post-Brexit so that higher capital outflows in the context of risk diversification could be a result of Brexit.

Acknowledgements This paper is part of EIIW research funded by the Deutsche Bundesbank. While the authors gratefully acknowledge funding from the Deutsche Bundesbank within the project "The Influence of Brexit on the EU28: Banking and Capital Market Adjustments as well as Direct Investment Dynamics in the Eurozone and other EU Countries", opinions expressed within represent those of the authors and do not reflect the views of the Deutsche Bundesbank or its staff. We also appreciate support from the Schumpeter School Foundation, Wuppertal, which allows this paper to be published as open access. We thank Manfred Kremer (European Central Bank), Tobias Gruhle (Johannes Gutenberg-University), Samed Krüger (University of Wuppertal) and participants of the workshop The Influence of Brexit on the EU28: Banking and Capital Market Adjustments (IHS Markit, Frankfurt, 2018) and International Rome Conference on Money, Banking and Finance (LUISS Guido Carli, Rome, 2018). We gratefully acknowledge editorial assistance by David Hanrahan (EIIW) as well as data assistance by Behailu Shiferaw Benti and Valeryia Siarheyeva. We are especially indebted to Prof. Dr. Paul J.J. Welfens for many valuable suggestions and comments. The usual disclaimer applies. 


\section{Appendix}

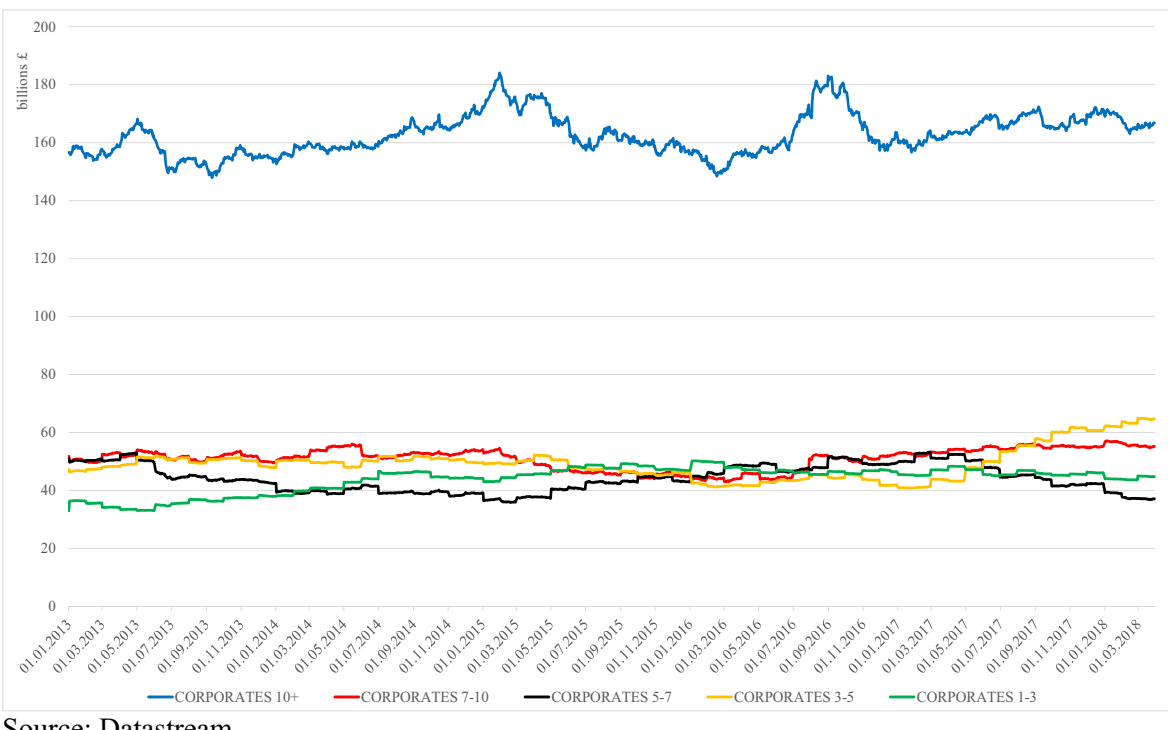

Source: Datastream

Fig. 2 Market Volume, UK Corporate Bond Market (Overall Economy, Daily Data, January 2013 March 2018)

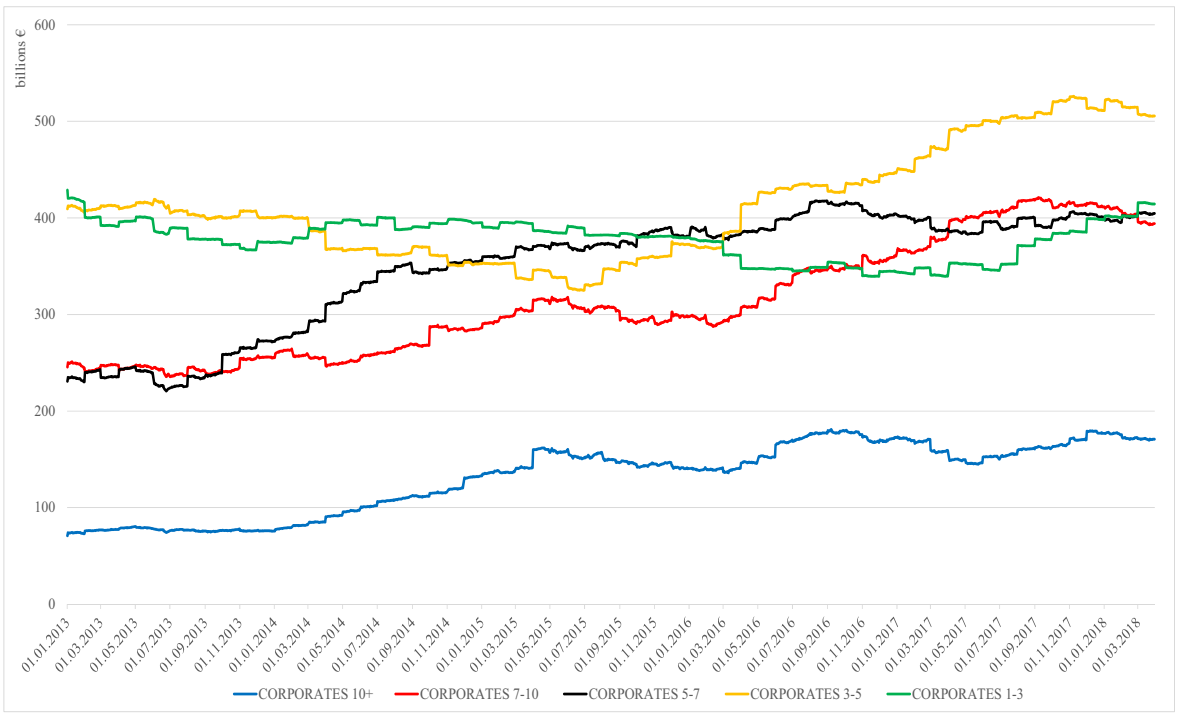

Source: Datastream

Fig. 3 Market Volume, EA Corporate Bond Market (Overall Economy, Daily Data, January 2013 March 2018) 
Open Access This article is distributed under the terms of the Creative Commons Attribution 4.0 International License (http://creativecommons.org/licenses/by/4.0/), which permits unrestricted use, distribution, and reproduction in any medium, provided you give appropriate credit to the original author(s) and the source, provide a link to the Creative Commons license, and indicate if changes were made.

Publisher's Note Springer Nature remains neutral with regard to jurisdictional claims in published maps and institutional affiliations.

\section{References}

Acharya VV, Amihud Y, Bharath ST (2013) Liquidity risk of corporate bond returns: conditional approach. J Financ Econ 110(2):358-386

Acharya VV, Drechsler I, Schnabl P (2014) A pyrrhic victory? bank bailouts and sovereign credit risk. J Financ 69(6):2689-2739

Amato JD, Remolona EM (2003) The credit spread puzzle. BIS Quart Rev 2003:51-64

Amihud Y, Mendelson H (1986) Asset pricing and the bid-ask spread. J Financ Econ 17(2):223-249

Augustin P, Boustanifar H, Breckenfelder J, Schnitzler J (2016) Sovereign to corporate risk spillovers, ECB working papers series, no. 1878, January 2016, revisited June 2018, forthcoming in Journal of Money, Credit and banking

Bank of England (2016) Inflation report may 2016, London

Bedendo M, Colla P (2015) Sovereign and corporate credit risk: evidence from the Eurozone. J Corp Finan 55(c):34-52

Belke A, Dubova I, Osowski T (2016) Policy uncertainty and international financial markets: the case of Brexit, Ruhr Econ Pap 657

Bernoth K, Erdogan B (2012) Sovereign bond yield spreads: a time-varying coefficient approach. J Int Money Financ 31(3):639-656

Black F, Cox J (1976) Valuing corporate securities: some effects of bond indenture provisions. J Financ 31(2): 351-367

Black F, Scholes M (1973) The pricing of options and corporate liabilities. J Polit Econ 81(3):637-654

Boneva L, de Roure C, Morley B (2018) The impact of the Bank of England's corporate bond purchase scheme on yield spreads, Bank of England, working paper no. 719

Campbell JY, Taksler GB (2003) Equity volatility and corporate bond yields. J Financ 58(6):2321-2350

Caporale GM, Gil-Alana L, Trani T (2018) Brexit and uncertainty in financial mar-kets. Int J Fin Stud 6(1):21

Chakravarty S, Sarkar A (1999) Liquidity in U.S. fixed income markets: a comparison of the Bid-Ask Spread in Corporate, Government and Municipal Bond Markets, FRB of New York Staff Report No. 73, March 1999. Available at SSRN: https://ssrn.com/abstract=163139 or https://doi.org/10.2139/ssrn.163139

Chen H, Cui R, He Z, Milbradt K (2018) Quantifying liquidity and default risks of corporate bonds over the business cycle. Rev Financ Stud 31(3):852-897

Chen L, Collin-Dufresne P, Goldstein RS (2009) On the relation between the credit spread puzzle and the equity premium puzzle. Rev Financ Stud 22(9):3367-3409

Chen L, Lesmond DA, Wei J (2007) Corporate yield spreads and bond liquidity. J Financ 62(1):119-149

Christensen J (2008) The corporate bond credit spread puzzle. FRBSF Economic Lett: 2008-10

Chun OM, Dionne G, François P (2014) Credit spread changes within switching regimes. J Bank Fin 49:4155

Collin-Dufresne P, Goldstein RS (2001) Do credit spreads reflect stationary leverage ratios? J Financ 56(5): 1929-1957

Collin-Dufresne P, Goldstein RS, Martin JS (2001) The determinants of credit spread changes. J Financ 56(6): 2177-2207

Davies RB, Studnicka Z (2017) The heterogeneous impact of Brexit: early indications from the FTSE. CESifo Working Papers 6478

Deutsche Bundesbank (2017) Monthly report, January 2017. Deutsche Bundesbank, Frankfurt am Main

Dick-Nielsen J, Feldhütter P, Lando D (2012) Corporate bond liquidity before and after the onset of the subprime crisis. J Financ Econ 103(3):471-492

Dötz N (2014) Decomposition of country-specific corporate bond spread. Deutsche Bundesbank, Discussion Paper, No. 37/2014 
Duffee GR (1998) The relation between Treasury yields and corporate bond yields. J Financ 53(6):2225-2241

Duffee GR (1999) Estimating the Price of default risk. Rev Financ Stud 12(1):197-226

Duffie D, Singleton K (1999) Modeling term structures of Defaultable bonds. Rev Financ Stud 12(4):687-720

ECB (2014) Euro area risk-free interest rates: measurement issues, recent developments and relevance to monetary policy. ECB Monthly Bull 2014:63-78

Elton EJ, Gruber MJ, Agrawal D, Mann C (2001) Explaining the rate spread on corporate bonds. J Financ 56(1):247-277

Fama EF, French KR (1993) Common risk factors in the returns on stocks and bonds. J Financ Econ 33(1):356

Feldhütter P, Schaefer SM (2018) The myth of the credit spread puzzle. Rev Financ Stud 31(8):2897-2942

Friewald N, Jankowitsch R, Subrahmanyam MG (2012) Illiquidity or credit deterioration: a study of liquidity in the US corporate bond market during financial crises. J Financ Econ 105(1):18-36

Goldstein R (2010) Can structural models of default explain the credit spread puzzle?. FRBSF Economic Letter, 2010-06

Gordon MJ, Shapiro E (1956) Capital equipment analysis: the required rate of profit. Manag Sci 3(1):102-110

Hotchkiss ES, Ronen T (2002) The informational efficiency of the corporate bond market: an intraday analysis. Rev Financ Stud 15(5):1325-1354

Houweling P, Mentink A, Vorst T (2005) Comparing possible proxies of corporate bond liquidity. J Bank Financ 29(6):1331-1358

Huang J-Z (2010) The structural approach to modeling credit risk. In: Lee C-F, Lee AC, Lee J (eds) (2010), handbook of quantitative finance and risk management. Springer, Boston, MA

Huang J-Z, Huang M (2012) How much of the corporate-Treasury yield spread is due to credit risk? Rev Asset Pric Stud 2(2):153-202

Jarrow R, Turnbull S (1995) Pricing derivatives on financial securities subject to default risk. J Financ 50(1): 53-86

Klein AC, Pliszka K (2018) The time-varying impact of systematic risk factors on corporate bond spreads, discussion papers no. 14/2018, deutsche Bundesbank, Frankfurt am Main

Klose J, Weigert B (2013) Sovereign yield spreads during the euro-crisis - fundamental factors versus redenomination risk, German Council of Economic Experts, working paper 07/2012, revisited

Korus A, Celebi K (2018) The impact of Brexit on the British pound/euro exchange rate, EIIW discussion paper no. 243

Krylova (2016) Determinants of euro-denominated corporate bond spreads. European Central Bank, working paper no. 1912

Leake J (2003) Credit spreads on sterling corporate bonds and the term structure of UK interest rates. Bank of England, working paper no. 202

Lin H, Wang J, Wu C (2011) Liquidity risk and expected corporate bond returns. J Financ Econ 99(3):628650

Liu S, Shi J, Wang J, Wu C (2009) The determinants of corporate bond yields. Quart Rev Econ Financ 49(1): 85-109

Longstaff FA, Mithal S, Neis E (2005) Corporate yield spreads: default risk or liquidity? New evidence from the credit default spread market. J Financ 60(5):2213-2253

Longstaff FA, Schwartz E (1995) A simple approach to valuing risky fixed and floating rate debt. J Financ 50(3):789-820

Merton R (1974) On the pricing of corporate debt: the risk structure of interest rates. J Financ 29(2):449-470

Pavlova I, Hibbert AM, Barber JR, Dandapani K (2015) Credit spreads and regime shifts. J Fixed Income 25(1):58-74

Ramiaha V, Phama HNA, Moosab I (2017) The sectoral effects of Brexit on the brit-ish economy: early evidence from the reaction of the stock market. Appl Econ 49(26):2508-2514

Schuknecht L, von Hagen J, Wolswijk G (2010) Government bond risk premiums in the EU revisited: the impact of the financial crisis. ECB working paper no. 1152, Frankfurt am Main

Schultz P (2001) Corporate bond trading costs: a peek behind the curtain. J Financ 56(2):677-698 